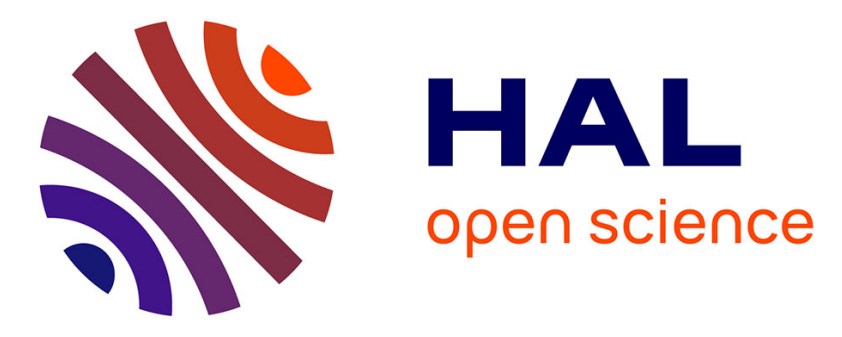

\title{
The transversal seismicity action RESIF : a tool to improve the distribution of the French seismicity products
}

Frédéric Masson, Samuel Auclair, Didier Bertil, Marc Grunberg, Bruno Hernandez, Sophie Lambotte, Gilles Mazet-Roux, Ludmila Provost, Jean-Marie Saurel, Antoine Schlupp, et al.

\section{To cite this version:}

Frédéric Masson, Samuel Auclair, Didier Bertil, Marc Grunberg, Bruno Hernandez, et al.. The transversal seismicity action RESIF : a tool to improve the distribution of the French seismicity products. Seismological Research Letters, 2021, 92 (3), pp.1623 - 1641. 10.1785/0220200353 . hal03195727

\section{HAL Id: hal-03195727 \\ https://hal.science/hal-03195727}

Submitted on 12 Apr 2021

HAL is a multi-disciplinary open access archive for the deposit and dissemination of scientific research documents, whether they are published or not. The documents may come from teaching and research institutions in France or abroad, or from public or private research centers.
L'archive ouverte pluridisciplinaire HAL, est destinée au dépôt et à la diffusion de documents scientifiques de niveau recherche, publiés ou non, émanant des établissements d'enseignement et de recherche français ou étrangers, des laboratoires publics ou privés. 


\title{
The transversal seismicity action RESIF : a tool to improve the distribution of the French seismicity products
}

Frédéric Masson ${ }^{1,2}$, Samuel Auclair ${ }^{3}$, Didier Bertil $^{3}$, Marc Grunberg $^{1}$, Bruno Hernandez $^{4}$, Sophie Lambotte ${ }^{1,2}$, Gilles Mazet-Roux ${ }^{4}$, Ludmila Provost ${ }^{5}$, Jean-Marie Saurel ${ }^{6}$, Antoine Schlupp ${ }^{1,2}$, Christophe Sira ${ }^{1}$

1 - EOST, Université de Strasbourg/CNRS, 5 rue Descartes, 67084 Strasbourg Cedex, France 2 - ITES, Université de Strasbourg/CNRS, 5 rue Descartes, 67084 Strasbourg Cedex, France 3 - BRGM, Department of Risks and Prevention, 3 av. Claude-Guillemin - BP 36009, 45060 Orléans Cedex 2 - France

4 - CEA, DAM, DIF, 91297 Arpajon, France

5 - Bureau d'évaluation des risques sismiques pour la sûreté des installations, Institut de Radioprotection et Sûreté Nucléaire, Fontenay-aux-Roses, France 6 - Université de Paris, Institut de physique du globe de Paris, CNRS, F-75005- Paris, France

Corresponding auteur : Frédéric MASSON, frederic.masson@unistra.fr

\begin{abstract}
In recent years, the French seismological, geodetic and gravimetric community has been structured within RESIF (French seismological and geodetic network). In addition to instrumental developments, RESIF has structured the work on French seismicity
\end{abstract}


(metropolitan and overseas) within the RESIF transverse seismicity action (ATS). The purpose of this article is to present the ATS and the way it is structured to propose to the community different products: seismicity bulletin and catalogue, historical and instrumental macroseismicity data, shakemaps. The places where these products can be found are indicated, as well as the way they are realized and the improvements in progress for a better realization and availability. The link with EPOS (European plate observing system) is also underlined.

Key words : French seismicity, bulletins and catalogues, macroseismicity data, shakemap. 


\section{Introduction}

Over the past ten years, the French seismological, geodetic and gravity communities have been structured within RESIF (French seismological and geodetic network). After having worked hard on the development of new seismological networks, in particular the RLBP (Permanent Broadband Network), and on the modernisation of data management and distribution, it appeared necessary to develop a transversal RESIF action dedicated to French seismicity. The purpose of the transversal seismicity action RESIF (ATS) is to coordinate all seismicity works within a single structure in order to increase the efficiency of the work carried out and its visibility. This includes the production and distribution of products derived from RESIF data on the knowledge of French seismicity and associated hazard.

The ATS is subdivided into 6 axes dedicated to the following topics: the construction of a multiorigin seismicity bulletin in France, the constitution of a reference catalogue of seismicity in France, the collection and analysis of macroseismic data (historical and contemporary seismicity in France), the implementation of shakemap at the national level integrating both macroseismic and instrumental seismic data (accelerometric and velocimetric), the study of faults that produce earthquakes with surface ruptures in metropolitan France during Quaternary and finally the creation of a working group for the study and characterization of seismic hazard at the national level.

The ATS is led by thirteen members of the RESIF Consortium: Geological and Mining Research Bureau (BRGM), Centre national de la recherche scientifique - Institut national des sciences de l'Univers (CNRS-INSU), Commissariat à l'énergie atomique et aux énergies alternatives (CEA), Institute of Earth Physics of Paris (IPGP), Institute for Radiation Protection 
and Nuclear Safety (IRSN), French Institute of Transport, Planning and Network Sciences and Technologies (IFFSTAR), Universities of Nice (OCA), Clermont-Auvergne, Montpellier, Nantes (OSUNA), Strasbourg (EOST, including BCSF-RéNaSS), Grenoble-Alpes (OSUG) and Paul Sabatier in Toulouse (OMP).

In this article, we present the work carried out by the first 4 axes of the ATS, which are closely related to the acquisition of seismic data (being instrumental or macroseismic). The ten members involved in these axes are listed in table 1a and their specific contribution in table $1 \mathrm{~b}$.

\section{Axes 1 and 2: Multi Origin Bulletin and Reference Catalogue}

In metropolitan France, several actors are involved in seismicity monitoring and analysis, either at a national level (CEA, BCSF-RéNaSS) or at a regional scale (Observatoire Midi Pyrénées (OMP-Toulouse), Observatoire des Sciences de l'Univers de Grenoble (OSUG), Observatoire de la Côte d'Azur (OCA-Nice) and Observatoire des Sciences des l'Univers Nantes Atlantique (OSUNA)), based on the analysis of data acquired by the RESIF and CEA seismic network

(figure 1), as well as other French or border networks. In the overseas French departments (Martinique, Guadeloupe, La Réunion), IPGP is in charge of the monitoring of each island active volcano and its surrounding regional seismicity (see below). There is a volcanological and seismological observatory on each island: Observatoire Volcanologique et Sismologique de Martinique (OVSM), Observatoire Volcanologique et Sismologique de Guadeloupe (OVSG) and Observatoire Volcanologique du Piton de la Fournaise (OVPF), respectively. With the intent to federate the different initiatives on seismicity, one of the objectives of the ATS is to produce a multi-origin bulletin for France (metropolitan and overseas territories), as 
comprehensive as possible, integrating the locations of the different agencies involved in seismicity monitoring. This action is a continuity of the collaborative work carried out in the Si-Hex project (completed in 2014), dedicated to the creation of a reference catalogue of seismicity in the metropolitan territory covering the period 1962-2009 (Cara et al., 2015). The result of this work is available on the website of franceseisme, and will soon be integrated into the multi-origin bulletin.

This bulletin will be updated as additional information becomes available. It will take into account late specific works (seismicity from temporary networks, relocations in specific studies such as $\mathrm{PhD}$ ). The bulletin will be made available through the FDSN webservice (http://renass.unistra.fr), identified as the one used by EIDA for French seismicity. Most of the associated waveforms are available from RESIF EIDA node (Strollo et al. 2020).

National Agencies Contributing to the Metropolitan Bulletin

\section{BCSF-RéNaSS}

The BCSF-RéNaSS is a component of the French National Observation Service in Seismology, labelled by the CNRS-INSU. It was born from the need to federate the existing regional seismic networks and to improve the instrumental coverage of France in the early 1980s with the installation of new stations to reach a total number of about 75 short-period stations spread throughout metropolitan France. Since the 2010's, in addition to the upgrade of the short-period network (progressive shift to a broadband network), the RESIF-RLBP research infrastructure has made it possible to densify the monitoring network to more than 160 broad band stations (mainly Streckeisen STS-2, Nanometrics Trillium 120 or Trillium 240, Guralp CMG-3) with a 
huge acceleration in the deployment from 2016. Few stations are present in the northern part, but a few more are planned in the coming years in the framework of RESIF.

The BCSF-RéNaSS, through its central site located at the Ecole et Observatoire des Sciences de la Terre (EOST) in Strasbourg, is in charge of:

- the monitoring of the seismic activity in metropolitan France and border areas,

- the discrimination between natural and anthropogenic seismicity (man-made or man-induced: mining activities, explosions, demining, geothermal energy production, ...),

- the determination and dissemination of earthquake source parameters (location of the hypocenter, time of origin, magnitudes, ...) on its website,

- macroseismic data collection, intensities evaluation, and shakemap realization (see below),

- the centralization, archiving and dissemination of seismological data for Earth Sciences research purposes (newsletters/catalogues),

- the transmission of source parameters to international seismological centers (EMSC, ISC),

- the public and media information.

At the operational level, the service carries out rapid (automatic and non-validated) and routine (manual, validated) locations of all seismic events detected, using signals from all the RESIFRLBP stations, but also from networks of neighboring countries (Germany, England, Belgium, Spain, Italy, Luxembourg, Switzerland). In addition, the BCSF-RéNaSS also uses temporarily deployed networks such as AlpArray (AlpArray Seismic Network, Hetényi et al. (2018)) or those of citizen seismology projects using RaspberryShake stations (Schlupp et al., 2019a).

Since 2012, the seismicity analysis has been carried out using the Seiscomp3 software with the Locsat earthquake location program (Bratt and Nagy, 1991). A 1D velocity model for 
metropolitan France is used : Haslach (Rothé and Peterschmitt, 1950) as well as 1D regional velocity models for the Pyrenees (Pauchet et al., 1999), the Alps (Thouvenot et al., 2003) and the Massif Central (Mazabraud et al., 2005).

Furthermore, one of the important steps of the seismicity analysis consists in discriminating natural earthquakes from anthropogenic events and other natural events. Most of these nonnatural events are linked to quarries activities, but also marine explosions or induced events. They are recorded and tagged. Discrimination is based on the experience of seismologist analysts (presence of low-frequency surface waves, P/S amplitude ratio, shallow depths, proximity to a quarry), and on some additional available information (communication from maritime authorities, ...). For induced events, discrimination is currently carried out using criteria such as proximity to a geothermal site, known geothermal activities, knowledge of the past seismicity in the region (Davis et al. 93).

Locations are validated and updated during working days (Monday to Friday) by a seismologist analyst. BCSF-RéNaSS locates several thousand events per year in metropolitan France and in border areas, more than 7,000 in 2019 (figure 2). The recent increase in the number of RLBP stations ( since 2016) has led to a completeness magnitude close to 1.8 at the national scale, with regional disparities. For instance, the improvement in detection level as well as in magnitude completeness is significant in the north-western part of the territory, in which the number of stations has increased the most, and less in the Alps where the network was already dense.

In recent years, the evolution of the seismic network and data analysis practices have led to a strengthening of collaboration and exchanges with regional observatories (in particular with OMP, OSUG, OCA and recently with OSUNA) in order to better integrate the earthquake 
locations done by these observatories, to improve the visibility of the work done, and to benefit from cross-expertise, particularly on discrimination (natural versus anthropogenic activities).

\section{$\underline{\mathrm{CEA}(\mathrm{LDG})}$}

The CEA (LDG: Laboratoire de Détection et de Géophysique) seismic network is the first and the oldest permanent seismic network installed in metropolitan France (Nicolas et al., 1998). This network now consists of 43 seismic stations equipped with a vertical short-period (1s) seismometers named ZM500 and developed in-house. Sixteen of these stations are also equipped with broadband sensors (Streckeisen STS-2 or Nanometrics Trillium T120). The waveforms of the T120 sensors are shared in real time with the scientific community in the framework of RESIF project. Ultimately 18 of CEA stations will be part of RESIF permanent broadband network.

The CEA has been producing a seismological bulletin for metropolitan France since the 60's which now contains nearly 70,000 earthquakes. In the initial phase of the bulletin production, the CEA analysts review the background noise recorded by its 43 stations and locate all natural or suspected induced events. To better constrain epicentral locations and hypocentral depths, the waveforms of nearby stations available via RESIF or GEOFON seedlink servers are also used. For earthquakes located in border regions, additional phases provided by other networks (French or foreign) are integrated.

As for the discrimination, the BCSF-RéNaSS and the CEA use similar procedures mostly based on the analysts' experience and on the signal frequency content. The CEA moreover uses waveform comparison as an additional tool to help in the discrimination process. 
Earthquakes are located via an earthquake location algorithm developed by the CEA (Nicolas et al., 1998) and based on the least squares method. The location algorithm uses a 1D threelayer velocity model composed of a thin sedimentary subsurface layer $(0.9 \mathrm{~km})$ above a thick continental crust $(25 \mathrm{~km})$ with an average ratio between the P- and S-wave velocities of 1.69. The Moho discontinuity is considered at $25.9 \mathrm{~km}$ depth (Veinante-Delhaye and Santoire, 1980).

For each event, a local (ML) magnitude is computed with an attenuation law determined in the 70's by the CEA (Duverger et al., subm.). It is often observed that the local magnitude computed by the CEA is a bit higher that those computed by other institutes. The reason lies in the use of this specific attenuation law which considers stronger attenuation with respect to the epicentral distance compared to these institutes. However, the strength of this ML is that its formula and its attenuation law have not changed since the 70's. The ML is computed only on the 43 CEA stations and only for epicentral distances larger than $95 \mathrm{~km}$. When the ML cannot be calculated, a duration (MD) magnitude is determined. Over the last decade, the completeness magnitude of the LDG bulletin is approximately $\mathrm{ML}=1.8$ (Duverger et al., subm.).

The seismic bulletins are published on a weekly basis in GSE2.0 format on the CEA website (http://www-dase.cea.fr) and are also sent to the ISC. Although the GSE2.0 bulletins only contain natural events and the seismic phases picked on CEA stations, the complete bulletins (with anthropogenic events and the complete list of seismic phases) are sent to the BCSFRéNaSS in QuakeML 1.2 format.

In addition to the seismic bulletin, the CEA produces automatic locations for events located in the French metropolitan territory and the surrounding areas and publishes them on its web site. 
These automatic locations are also sent to the EMSC but without any verification or discrimination. As a result, some of them, which turned out to be marine explosions, may finally remain in the EMSC real time catalogue.

For earthquakes of magnitude larger than 3.5 in the metropolitan territory, the CEA is in charge of rapidly informing the civil security but also other institutions like EDF (French electric utility company), Andra (French agency for the management of radioactive wastes) and SNCF (French state-owned railway company) through specific contracts. The location algorithm, the velocity model and the attenuation law used in the automatic location system are the same as for the production of the seismological bulletin and are described above.

Finally, the CEA also hosts the National Tsunami Warning Centre (Cenalt, Gailler et al., 2013; Schindelé et al., 2015), responsible for the dissemination of rapid information (in less than 15 minutes) to the authorities for any seismic event in the Mediterranean sea and the NE Atlantic ocean likely to generate a tsunami threatening the metropolitan coasts. The epicenter locations disseminated in this context are mostly automatic but always validated by an analyst.

The CEA is now interested in evaluating the accuracy of the epicenter locations in its bulletin using the GT5 (Ground Truth) criteria, which ensure that a location has an accuracy of $5 \mathrm{~km}$ with 95\% confidence. These criteria are defined by Bondár et al. (2009) and are based on the geometry of the network. The application of these criteria to the LDG bulletin shows that since 2012, more than $70 \%$ of the locations are GT5 (figure 3). This performance is mainly due to the integration of new stations, especially those of the RESIF-RLBP, which allows a better constraint of the locations. The next step will be to determine our own GT criteria through a statistical approach, from a selection of reference events. Belinić et al. (2017) showed that the 
criteria of Bondár et al. (2009) are very conservative and that each network could calculate its own criteria and finally increase the number of well constrained locations. Ultimately, the objective is to assign to each location a quality factor for bulletin and/or catalogue users, ranging from A (GT5 location) to D (very poorly constrained location). The CEA also aims at determining a similar quality factor for focal depth and magnitude.

\section{French Overseas Department Seismicity}

Since more than 40 years, IPGP is in charge of volcanic and seismic monitoring of the three French departments that host an active volcano. In Indian Ocean, Piton de La Fournaise and neighboring seismicity in La Réunion are monitored by OVPF since 1978. In the Caribbean, Soufrière de Guadeloupe volcano is monitored by OVSG since 1956 and Montagne Pelée volcano in Martinique is monitored by OVSM since 1902. Antilles arc subduction zone seismicity in the vicinity of Martinique, Guadeloupe, Saint-Martin and Saint-Barthélémy is jointly monitored by OVSM from Saint-Vincent to Dominica and OVSG from Dominica to Anguilla. In June 2018, the Mayotte seismic-volcanic crisis associated to the fourth French overseas active volcano, has strengthened the collaborative work between the different institutes (BCSF-RéNaSS, BRGM and IPGP) in particular to ensure the seismicity monitoring within the framework of REVOSIMA (Volcanological and Seismological Monitoring Network of Mayotte with BRGM, CNRS, IFREMER and IPGP) which is the French official structure in charge of monitoring volcanic and seismic activity in the Mayotte region. In June 2020 the IPGP data center started distributing in real-time an fdsnws-event seismicity catalogue of manually validated earthquakes from its 3 observatories. Those 4 catalogues (Martinique, Guadeloupe, La Réunion, Mayotte) are now available through fdsnws-event webservice but also on the BCSF- RéNaSS website. 
Future Developments and Challenges for a Quality Bulletin

In the continuity of the Si-Hex project that led to the creation of a reference catalogue of seismicity on the metropolitan territory over the period 1962-2009 (Cara et al., 2015), work is currently being carried out to complete the bulletin over the period 2010 to 2018 . Within this framework, a first step was to produce a new earthquake location by merging the picks of the two national agencies (BCSF-RéNaSS and CEA/LDG). The next steps will consist in integrating the locations made by regional observatories (OCA, OMP, OSUG, OSUNA). Each observatories have its own earthquake location procedure with velocity models that can be different (1D or 3D models), as well as location software, discrimination processes (for more details see Cara et al., 2015), and stations used (generally a subset of stations presented in Figure 1 and located in their region of interest with potentially additional regional velocimetric or accelerometric stations, or stations from temporary networks or foreign countries). After merging, quality criteria will be defined to identify the preferred location in an objective way, i.e. with the best constraint. These preferred earthquake locations will constitute the reference catalogue of seismicity of metropolitan France. In addition, in the continuation of the work initiated within the framework of Si-Hex on the estimation of moment magnitudes (Cara et al., 2015; Denieul et al., 2015), an effort is being made to compute moment magnitudes Mw from the inversion of S-wave spectra (using SourceSpec software, Satriano, C.) for as many events as possible. This work will be the base to set up a procedure to regularly update the multi-origin bulletin.

In order to produce a valuable metropolitan seismicity bulletin, as comprehensive as possible, which is crucial for many hazard studies, or any statistical analysis of seismicity, several issues 
have been identified and will be the subject of future work. With the recent development of the RLBP seismic network, one of the important challenges concerns the discrimination between natural and anthropogenic events, particularly related to quarry activities, the number of anthropogenic events having drastically increased and constituting the majority of the automatic detections. Indeed, with the development of the network in areas where there were previously no stations, and thanks to an overall lowering of the magnitude of completeness, more and more quarry blasts are being detected. Machine learning methodologies are currently being explored to improve this discrimination (Renouard et al., 2020).

The recent development of the RLBP network, and the various initiatives led by the scientific community - PYROPE project (Chevrot et al., 2014) and ALPArray (AlpArray Seismic Network, Hetényi et al. 2018) - will allow the construction of 3D velocity models at national or regional scale, and thus improve the earthquake locations and the evaluation of the associated uncertainties, especially on the depth of the events, an important parameter in seismic hazard studies. In addition, focal mechanisms will be integrated into the multi-origin bulletin when available.

\section{Axis 3: Collection and analysis of historical and contemporary macroseismic data}

Macroseismic intensity represents the severity of the ground shaking. It is determined for contemporary earthquakes from I to XII on the European macroseismic scale (EMS98 Grünthal, 1998). This non-instrumental data is estimated on the basis of the observable effects produced by seismic shakes: effects on people, objects, furniture, buildings and the environment. It allows, in a very general way, to specify the directivity effects often linked to 
the effects of sources (Courboulex et al., 2013), to better understand the decrease of seismic movements with distance (Baumont et al., 2018, Bakun and Scotti, 2006), or to highlight local modulations linked to site effects (Bossu et al., 2000; Sbarra et al., 2012), due to particular topographic or geological local configurations.

Axis 3 of the ATS aims to conduct a reflection to facilitate the collection, analysis and dissemination of contemporary and historical macroseismic information. It works towards a rapprochement between data "producers" and "users" according to levels of use. In particular, it implies progress in the qualification of macroseismic data (metadata and general conditions of use), modes of representation and dissemination.

\section{Contemporary Macroseismic Data Collection}

Since the year 2000, when an earthquake occurs, and following the example of the USGS "Did you feel it" questionnaires (Atkinson and Wald, 2007), the first macroseismic data are collected spontaneously via an open testimony interface. Anyone who has felt the effects of a shake potentially linked to an earthquake can provide, via a questionnaire, details of the observed effects through a field of questions, itself parameterised on the EMS98 scale. A specific version of the form has been generated for each of the French territories: a form for metropolitan France, and forms for the various overseas territories (West Indies, French Guiana, Mayotte, Reunion Island). Thus and in a quasi-systematic way, the BCSF-RéNaSS receives the first testimonies within a minute after the earthquake. According to a method used in 2009 in the SISMOCOM application (Sira et al., 2010), the characteristic macroseismic effects associated with the different degrees of the EMS-98 scale are summarized at the end of the form with illustrative thumbnails to be selected by the witness. These thumbnails allow to qualify the level of shaking 
at the individual scale. The average of these values at the commune level makes it possible to deduce a preliminary intensity value, which can be used in rapid time for the direct realization of macroseismic maps (figure 4), or to calibrate the calculation of shakemaps (Atkinson and Wald, 2007) or other specific applications.

The site of Franceseisme opens, for each earthquake of local magnitude greater than or equal to 3.7 (ML CEA) in metropolitan France or for any earthquake felt overseas (observatories of IPGP), a specific page to the earthquake and calls on testimonials on Facebook and Twitter social networks (@franceseisme). Beyond the magnitude 3.7, the BCSF-RéNaSS launches a macroseismic survey within 48 hours with the local authorities (town halls, gendarmeries, fire stations) via the prefectures of the departments. The survey form enables the authorities to transmit a precise and calibrated statistical summary of the effects on the scale of the commune. This data is not acquired in rapid time, but its consolidated form, validated by the authorities, is the basis for the estimate of the final communal intensities. If they are sufficiently numerous to be representative for the commune, the individual testimonies are also integrated into our estimate.

After the occurrence of an earthquake generating damage to buildings of degree 3 or higher according to the EMS-98 classification, a Macroseismic Intervention Group (GIM) is sent to the field to collect the macroseismic effects on common indicators like people, objects, furnitures and more specifically effects on the buildings to deduce communal intensity (Sira, 2015). This value, derived from in-situ observations by experts, dominates all the other data (i.e. individual testimonies and collective questionnaires). This group, led by BCSF-RéNaSS, is composed of about sixty experts from different French institutes involved in seismological studies and also works in cross-border collaboration with Spain and Andorra for the Pyrenees 
(POCRISC project) and Belgium (ORB) for northern France. Dedicated and trained teams are operational in the West Indies.

Available Macroseismic Products

\section{Contemporary Macroseismicity}

Macroseismic products available to scientists, authorities or the general public are mainly :

- Preliminary macroseismic intensity data (rapid intensities from internet testimonials).

- Definitive macroseismic intensity data from all available data (MFC-DB - Contemporary Macroseismic Database). The MFC database contains nearly 181,000 digitized forms (after the year 1996) and more than 120,000 communal intensities since 1921, for nearly 2,000 recorded events.

- The paper archives of the macroseismic surveys represent since 1921 about 200,000 documents over 40 linear meters, archived at EOST. They are accessible on site by all scientists. In 2020, all the macroseismic investigation documents for earthquakes of intensity greater than VII over the period 1921-2020 have been digitized with the aim of safeguarding and valorizing them.

- The cartographies associated with each event widely felt by the population. This includes the maps of macroseismic effects (figure 5), the maps of preliminary and final intensities (figures 4 and 6), the isoseismal or choropleth maps obtained by interpolation (kriging or IDW). These maps are produced as part of the publication of BCSF-RéNaSS macroseismic reports (Sira et al., 2019) or annual seismological observations (Cara et al., 2007).

- Testimonies-comments from Internet users. 
On scientific request, we transmit all data collected in anonymous form for any study or research work. We associate cross-border data with European cross-border agencies in order to obtain complete macroseismic mapping of events affecting several countries (Cara et al., 2005). A webservice is functional at BCSF-RéNaSS and allows the distribution of preliminary intensities to authorized agencies. Finally (beginning of 2021) all intensity data and testimonial forms will be accessible through an API (Application Programming Interface) site in json format.

\section{$\underline{\text { Historical Macroseismicity }}$}

In France, the work of systematic characterization of historical seismicity through research and analysis of testimonies preserved in archives is carried out by the SISFRANCE consortium (BRGM, EDF, IRSN). The SISFRANCE macroseismic database (which covers the historical period and in part the contemporary period up to 2007) is the result of work begun nearly forty years ago and is still being constantly updated. Its objective is to guarantee the best state of knowledge of macroseismicity for the French territory (Scotti et al., 2004). To date, the SISFRANCE database contains more than 11,000 documents, recording more than 100,000 observations relating to nearly 6,300 events, including 5,695 real earthquakes. The SISFRANCE data are made public via the website www.sisfrance.net, with a three-yearly update periodicity, allowing for better consolidation of updates and a more stable work base for users. The online consultation allows, for a given earthquake, to consult the point and epicentral intensity values and their reliability code, the list of associated bibliographical references, or isoseismic maps established for the most important earthquakes. In addition, the downloading of all the epicentres of the database is proposed, as well as the downloading of all the 
observations associated with a given earthquake. In addition, the AHEAD European Historical Macroseismicity Database, Locati et al., 2014) also provides access to SISFRANCE data corresponding to earthquakes that occurred up to the 19th century.

\section{Data Usage, Valorisation and Dissemination}

Instrumental seismology appeared at the end of the 19th century, which is quite young compared to periods of return of earthquakes that can reach several centuries or even millenaries. Thus, the knowledge of historical earthquakes is decisive for the understanding of the seismic phenomenon and for the determination of the hazard level of territories, taking into account the recurrence time scales associated with the most destructive earthquakes. The ability, from the middle of the 20th century onwards, to measure seismic shakes ever more precisely, does not detract from the importance of macroseismic data. These two types of observations are very complementary.

In this respect, the study of historical sources is a fundamental step in the characterization of past earthquakes. While the study of the oldest earthquakes requires the search for mentions of the macroseismic effects reported incidentally in various documentary sources (parish archives, notarial deeds, journals of learned societies, etc.), the collection of information in an organized and systematic form only dates back to the 19th century in the world. In France, it is the BCSF (now BCSF-RéNaSS) that has been collecting macroseismic observations since 1921, using a systematic and standardized collection procedure.

A survey carried out by axis 3 in 2017, allowed to specify the main uses of the macroseismic data carried out in France: 
- Engineering seismology and earthquake engineering:

o The estimation of Intensity Prediction Equations (IPEs) (Baumont et al., 2018; Bakun and Scotti, 2006) and Ground Motion Intensity Conversion Equations (GMICEs) (Souriau, 2006), calibrated on contemporary earthquakes for which both instrumental measurements and macroseismic observations are available,

o The calculation of parametric catalogues allowing the estimation of hypocentric depth and magnitude values at ancient earthquakes, through the use of IPEs (Traversa et al., 2017; Provost and Scotti 2020; Manchuel et al., 2018).

o The determination of Seismic Hazard Assessment (SHA). Whether deterministic (DSHA) or probabilistic (PSHA), SHA studies are mainly based on historical macroseismic data that allow - going back to the distant past - more important earthquakes to be taken into account (Martin et al., 2002; Woessner et al., 2015).

o The characterization of site effects (Bossu et al., 2000).

o The calibration of rapid shakemaps, especially shakemaps expressed in macroseismic intensity, due to the large uncertainty in the intensity values converted from PGA/PGV measurements via GMICE for very high or very low ground motion (Gehl et al., 2017; Worden et al., 2020).

o Calibration of brittleness curves allowing to deduce a probability of damage to a structure from the level of seismic aggressiveness (Lagomarsino and Giovinazzi, 2006).

o Calculation of loss scenarios, for past earthquakes (Riedel et al., 2015) or in real time (Auclair et al., 2015a).

- Coverage of earthquake costs :

o The use of the macroseismic intensity established by the BCSF-RéNaSS as an important 
parameter to establish the list of communes eligible for compensation. In the French framework of the procedure for recognising the state of a natural disaster (guarantee allowing compensation for victims of rare natural events), the macroseismic intensities established by the BCSF are the main data used by the interministerial commission in charge of defining the list of disasterstricken communes whose economic losses are covered.

o Financial estimate of seismic risk (Rey and Tinard, 2015).

- Crisis management :

o Seismic scenarios (real or fictitious) expressed in macroseismic intensity maps, are the main tools available to civil protection to establish crisis management planning with regard to earthquakes.

o Following the occurrence of an earthquake, the civil protection bodies are accustomed to consulting the macroseismic maps immediately drawn up from individual testimonies, to assess the severity of the situation.

o In the absence of a dedicated instrumentation of their facilities, the operators of specific structures (e.g. engineering structures, transportation networks) use the macroseismic intensity to assess the need for a control of their structures.

- Others :

o Social scientists also work with macroseismic data to complete their studies on the behavior of populations in earthquake situations (Rojo et al., 2017). In this way, they help to improve prevention and resilience policies.

Numerous uses are thus made of macroseismic data and axis 3 works to improve information distribution systems by improving the metadata essential for appropriate use. It remains 
essential for axis 3 to work on making this macroseismic information available as quickly as possible through common interfaces and computer formats (GIS, Json format, etc.). The traceability and reproducibility of intensity estimation methods based on the macroseismic information collected is also a way to improve the quality of the data disseminated and the sustainability of production processes.

\section{Axis 4: implementation of Shakemaps}

The seismicity of France is considered moderate in its metropolitan part and more important in the West Indies due to a subduction context. Every year, dozens of earthquakes are felt and some reach EMS98 VI intensity, causing limited damage to the most vulnerable buildings. Others, rarer, reach higher intensities (Le Teil 2019 = I max VII-VIII; Arette 1967 or Les Saintes 2004 = Imax VIII; Basel 1356 or Camprodon-Olot 1428 or Valais 1855 or Imperia 1887 $=$ Imax IX) with a wider impact on buildings depending on their vulnerability. Beyond the maximum known intensity, knowledge of the regional distribution of shakes and its mapping, "shakemap", are essential (Wald et al., 1999). If this shakemap is produced and disseminated rapidly, it becomes a useful product for crisis management as it is one of the indispensable input data for estimating potential damage. But it is also a formidable tool for testing and comparing the parameters and models used in seismic hazard or even risk studies against reality.

Precise mapping of earthquake-induced shakes, shakemap, requires an understanding of the spatial variations of shakes, which are actually much more complex than those represented by the attenuation relationships. They are mainly due to the particularities of the source (mechanism, rupture size, directivity), propagation (spatial variability of attenuation) and site 
effects (geological or topographical). These parameters, which are difficult to specify for a given earthquake, ipso facto make a theoretical model of the shakes often unrepresentative, especially near the epicenter, a situation that is aggravated in the case of uncertainties about the magnitude and hypocentral location. Part of the solution is provided by instrumental measurements during the earthquake which serve as reference points for spatial correction of the shakemap. However, despite the development of seismological networks in France with about 400 sensors available on the metropolitan territory (RLBP but also RAP (Permanent Accelerometric Network) and few other stations including 40 RaspberryShakes), the distance between the epicenter and the nearest station is still often several tens of kilometres. This mesh remains too limited, especially to characterize the tremors under the 35,000 French communes, the vast majority of which are separated by less than $5 \mathrm{~km}$. This is where the macroseismic observations collected by the BCSF-RéNaSS in affected commune, and the intensities of the induced shakes (cf. axis 3 above), intervene to add as many reference points. It is in this spirit that version 3.5 of the USGS ShakeMap program was developed, integrating instrumental and macroseismic data, an approach retained in current version 4.0 (Worden et al. 2010, Worden et al. 2020).

The ShakeMap program (V3.5 or V4.0) allows to reconcile an a priori modelling (based on hypocenter, magnitude, ground motion or intensity versus distance (GMPE, IPE) and ground motion versus intensity (GMICE) relationships, and site effects), and real ground motion observations during the earthquake (based on instrumental and macroseismic data).

The objective of axe 4 , shakemap, is to generate a nationwide map of earthquake shakes, based on numerical modelling from source data (characteristics of the event) and earthquake propagation models (regional and local characteristics such as mitigation, site effects) while 
integrating all available instrumental and macro-seismic measures (Schlupp et al. 2019b).

Realization of the shakemap using the ShakeMap program

The program and the method used to carry out national shakemap operationally since 2016 (automatically online and shared results) are based on USGS version 3.5 of the ShakeMap program and the product is available for metropolitan France and West Indies (Guadeloupe, Martinique). The operational tool will be based on version 4.0 in 2021 and the products available online will then include Mayotte and La Réunion islands (overseas territories).

The "static" data are not dependent on the event. Some may vary geographically then taken into account by a zoning. This concerns soil amplification or site effects and the choice of attenuation relationships (Ground Motion Predictive Equations GMPE and Intensity Predictive Equations IPE). The conversion between intensity and velocity or intensity and acceleration (ground motion intensity conversion equations GMICE) is fixed and not geographically dependent. Site effects are based by default on the topographic slope proxi (Wald and Allen, 2007; Allen and Wald, 2009). Currently, Akkar and Bommer (2010) is the GMPE used in metropolitan France and the West Indies. For IPEs, Marin et al. (2004) was chosen for metropolitan France and Beauducel et al. (2011) for the West Indies. GMICE is from Caprio et al. (2015).

The "Event-specific" data as hypocenter and magnitude used are from the national seismological observatories in charge of seismic warnings (CEA in metropolitan France and IPGP-OVS in West Indies) and BCSF-RéNaSS. The focal mechanism, the size of the rupture and the directivity are data known later and not integrated in the automatic elaboration 
procedures of the shakemap product.

Observations on the level of the shakes come on the one hand from seismological permanent networks ( $\sim 400$ stations), and on the other hand from macro-seismic observations. The RESIF network, which includes Broad Band stations operated by LDG, as well as the IPGP seismological observatories and neighbouring countries, disseminate their instrumental, accelerometric and velocimetric measurements, in near real time.

The BCSF-RéNaSS collects macroseismic data (see axis 3, above) and provides intensities for the affected communes. Preliminary values are calculated automatically and are based on rapid testimonies from citizens in the minutes and hours following the earthquake on www.franceseisme.fr, their number often reaching several thousand for earthquakes of $\mathrm{Mw}>$ 4.5. The final EMS98 intensity values are based on detailed surveys and, in case of damage, dedicated field missions. For border countries, macroseismic data are currently shared rapidly with Italy and Spain in the framework of INTERREG projects. Seismic activity in metropolitan France is often located in border areas (Pyrenees, Alps, Jura, Rhine Graben). These exchanges of instrumental and macroseismic data are essential.

Since 2018, in order to increase the number of instrumental measurement points, we have been integrating measurements made directly in the municipalities by low-cost sensors (Raspberry Shake) installed in private homes, particularly within the framework of the "SismoCitoyen" project (Schlupp et al., 2019b). In September 2020, about 40 RaspberryShakes are operational in the NE of France.

Instrumental observations, available very quickly for permanent stations connected 24 hours a 
day, remain spatially limited and rare in urban areas, the main target for seismic hazard and risk. For the intensities deduced from macroseismic data, spatially very dense, the quality and density of these data evolve over time. The number of online testimonials is increasing in the minutes and hours following the earthquake, covering more communes and making it possible to estimate more reliable communal intensities (based on more testimonials), despite preliminary. The final intensity is available after several weeks. The shakemap must therefore be scalable over time, from preliminary and rapid versions in the hours and days following the earthquake to a later finalized version.

Two major modifications have been made to the cartographic representation of the shakemap USGS program maps improving their quality analysis and feedback on the earthquake (figure 7). For the intensity maps, we have modified the color codes according to the intensity levels to those used at franceseisme.fr for many years. Intensity VI turns red (level of classification as a natural disaster in France and presence of degree 2 damage on vulnerable buildings) and there is a marked color variation for lower intensities. The intensities $\leq \mathrm{VI}$ are the most frequently observed in France as well as in a large part of Western Europe. We have also modified the display of observation points (instrumental and macro-seismic data) for each type of map (Intensity, PGA, PGV, PSA) (figures 7 and 8). The size of the circles representing the communal intensities and the triangles of the seismological stations is modulated according to whether or not they have been taken into account in the shakemap calculation (GMPE or IPE \pm 1,2 or 3 sigma depending on the choices, after application of bias if necessary). For the intensity maps, a background color is added to the communal intensities (circles) and to the intensities converted from GMPE-PGV at the seismological stations (triangles) following the color scale used in the shakemap. This representation allows at a glance to identify observation or modelling anomalies (poor hypocentral localization, non-optimal attenuation relationship, site 
effect badly taken into account, ...) and to have a critical look at the shakemap produced but also at the GMPE, IPE, GMICE or input data used.

\section{Products}

The first automatic and operational shakemaps in France are computed for the French-Spanish border area of the Pyrenees with the SISPYR Project (Bertil et al, 2012). Since December 2012, shakemaps have been produced for 144 earthquakes (ML_IGN-Madrid $\geq 3$ ) with integration of macroseismic data. Other regional shakemaps for South-East of France are produced since 2015 (CASSAT project - 10 to 20 shakemaps per year from 2015 to 2018) with integration of macroseismic data since 2018 (RISVAL project, sismoazur.oca.eu - several tens of shakemaps since the beginning of 2019). For more details, an in-depth comparison of these systems is presented by Guérin-Marthe et al. (2020).

Since 2016, shakemaps based on instrumental and macroseismic data are operational for the whole metropolitan France and West Indies and are available on the website of Franceseisme. They are produced for any earthquake subject to an alert from CEA in metropolitan France and IPGP in the West Indies with regular updates for 7 days. Since April 2016, 125 shakemaps for earthquakes that have been the subject of an alert (97 in metropolitan France and 28 in the West Indies) have been processed. The maps in Intensity, PGA, PGV and PSA and the data used (instrumental and macroseismic: "stationlist.txt") for each ShakeMap are available on the web site (figures 7 and 8).

At franceseisme.fr, the first automatic shakemaps (50\%) are produced and available online in less than 20' (between 3' and 20', average 9') after receiving the alert and are followed by 
automatic updates for 7 days. The manual shakemaps (50\%) are produced later due to noncompliant alert messages or manual earthquake alerts that are widely felt but have not been the subject of an alert in metropolitan France, and in a few cases of internal technical failures. Whether manual or automatic, the shakemap calculation time itself is of the order of the minute.

Since 2017, axis 4 of the ATS has been working on this theme and its potential for improvement and development. The shakemap is a transverse product, drawing on RESIF data from axes 1 , 2 and 3 of the ATS (bulletin, catalogues, macroseismic data) and illuminating axis 5 (seismic hazard).

\section{Future Developments}

The shakemap calculation evolves and improves with version 4 of the USGS program. Already used regionally by GeoAzur for the SE of France and being implemented in the Pyrenees (POCRISC project), it will be applied at the national level (metropolitan France, West Indies, Mayotte and La Réunion) during the merger of the BCSF and Rénass web sites and the important update that accompanies it.

USGS ShakeMap v4 constitutes a significant improvement over v3.5, especially regarding the replacement of the weighted interpolation algorithm by an updating approach based on the multivariate normal distribution of ground-motion estimates. The Bayesian algorithm for the derivation of shake-maps (Gehl et al., 2017) is currently running as a test version on BRGM's SeiSComp3 servers, generating shake-maps for the Pyrenees and Mayotte areas. The Bayesian algorithm gives identical results as the algorithm by Worden et al. (2018), on which USGS ShakeMap v4 is based (i.e., same mathematical concept using spatially-correlated Gaussian 
fields). For now, the Bayesian code may be used for $R \& D$ purposes, in order to integrate various types of uncertainties (e.g., spatial correlation models, site amplification factors) or to consider non-conventional types of observations (e.g., investigation of the added valued of social media data, such as Twitter feeds after an earthquake event (Fayjaloun et al., 2020). Such developments are currently on-going within the H2020 European project TURNkey.

Improvements should address the three pillars of Shakemap computation:

- the available data of the event and their quality (location, depth, magnitude, size of the activated fault, directivity, stress drop) and if necessary the methods to correct them in view of the observations (instrumental, macroseismic),

- the indispensable regionalization of the parameters used with their area of validity (attenuation, site effect) and the calculation of values outside the observation points (interpolation, modelling),

- the difference in behaviour between small and large earthquakes must be integrated.

Site effects are only integrated via the "topographic slope" proxi for the national calculation. Regional shakemaps for Pyrenees (SisPyr \& POCRISC projects) and SE France (CASSAT \& RISVAL projects), using amplification maps based on soil classes of type EC8 take better account of soil responses. An integration of BRGM ongoing work on site effects covering whole France will allow to better model these effects for the national calculation.

The Caribbean context presents additional regional specificities, with the taking into account of deep subduction earthquakes, and the adaptation of adjustment criteria, usually made at the level of epicentral zones, which is not yet possible without real-time instrumentation for earthquakes located at sea. Volcanic heterogeneous islands like La Réunion and Mayotte also 
pose local amplification problems.

The systematic realization of shakemap for any earthquake that has been the subject of an alert has made it possible to highlight gaps in the attenuation relationships and an overestimation of the magnitude in the Armorican zone (figure 9). It appears indispensable to use regionalized attenuation models (Bakun and Scotti, 2006), but remains to be built for GMPEs.

Shakemaps can be considered as scientific research tools that are frequently used as input for calculations, in association with other data (vulnerability, losses), for damage estimation. For example, the Interreg POCRISC project foresees rapid damage estimates with the shakemaps as input seismic motion. The interfacing between the shakemap outputs and the inputs of the damage tool Armagedom (Sedan et al., 2013) is operational. The automation of the process is in progress. A SEISAID alert is an automatic tool based on the PAGER approach (Auclair et al., 2015b) for the Civil Security, to give in quick response estimated damage and human balance sheets of a possible strong earthquake. This tool, developed by BRGM for metropolitan France, is currently being transposed for Mayotte following the seismic-volcanic crisis of 20182019. Next step will be its transposition to French West Indies. The input data are shakemaps. All of these tools are grouped together in a web platform under development (Tellez-Arenas et al., 2019)

Shakemap calculation has been developed mainly for rapid public information and decision support for emergency response. But this tool can also contribute to a wide range of research studies from the characterisation of historical earthquakes, bringing another light on the coherence between macroseismic data, estimated magnitudes and associated interpretations, until their comparison with complex direct calculations of seismic wave propagation from the 
fault to the site.

\section{Conclusion}

The ATS products described above (multi-origin bulletin, reference catalogue, macroseismic data, shakemaps) will soon be available on the new website of Franceseisme. This website will be redesigned and will integrate on a single web portal all the information on the seismicity in France most of them put online as soon as available: for the seismicity of metropolitan France (currently available on the website of te ReNaSS), but also the one affecting the West Indies (mainly Guadeloupe and Martinique, but more widely the seismicity of the whole arc), Mayotte and the Reunion Island. These data are available to the scientific and professional community, as well as to the public, as they are totally free of copyright. Each ATS axis leads technical groups that work to improve the methods used and the products delivered, and to ensure that the work carried out meets the expectations of the community.

All these described product are also the input data for the axis 6 of the ATS related to seismic hazard in France. This axis aims at encouraging interactions between all the actors involved in the study of seismic hazard (universities and CNRS laboratories, organizations such as BRGM, IRSN or CEA, public and private companies) in order to build a database to assess the seismic potential of seismic sources, and then to develop new seismic hazard models incorporating the latest research results. Within the framework of this axis 6 it is necessary to use standard data (seismicity catalogues, palaeoseismology, ...) but also more original data (geodesy, numerical modelling, ...) to better define seismotectonics and seismogenic properties in France. One of the long term objectives will be to build a seismic hazard reference model, which will serve as 
a basis for both research projects and seismic hazard calculation.

In a near future, to continue improving the quality and the dissemination of the products, the ATS will face several challenges, one of those is the inevitable evolution of data management and data analysis due to the huge increase of data amount and computing facilities. The improvement of the dissemination will require a better integration at the European level.

Since a few years, the ATS has been recognized as the French interlocutor for the TCS (Thematic Core Service) Seismology of EPOS (European Plate Observing System) and more particularly its two services EMSC (European-Mediterranean Seismological Centre) which is in charge of the seismological products and EFEHR (European Facilities for Earthquake Hazard and Risk) which delivers services for earthquake hazard and risk.

\section{Data and Ressources}

Data used for seismicity analysis are from the following networks :

- RESIF. (1995a).

- RESIF. (1995b).

- RESIF. (2018).

- Landesamt Fuer Geologie, Rohstoffe Und Bergbau. (2009).

- GEOFON Data Centre. (1993).

- (1) Raspberry Shake Community; (2) OSOP, S.A.; (3) Gempa GmbH. (2016).

- Institut De Physique Du Globe De Paris (IPGP), \& Ecole Et Observatoire Des Sciences De La Terre De Strasbourg (EOST). (1982).

- French Landslide Observatory - Seismological Datacenter / RESIF. (2006). 
- Instituto Geografico Nacional, Spain. (1999).

- University Of Genova. (1967).

- Federal Institute for Geosciences and Natural Resources. (1976).

- Swiss Seismological Service (SED) At ETH Zurich. (1983).

- Royal Observatory Of Belgium. (1985).

The reference catalog of the metropolitan France covering the period 1962-2009 (SiHEx project) is available at http://www.franceseisme.fr/sismicite.html.

The seismicity bulletin and catalog of BCSF-ReNaSS and those resulting from the axes 1 and 2 are or will be available at http://renass.unistra.fr (which will be integrated into the franceseisme site in 2021).

The seismicity bulletin of CEA-LDG can be found at http://www-dase.cea.fr.

The software SourceSpec (doi:10.5281/zenodo.3688587) currently tested for the moment magnitude computation can be downloaded at SourceSpec software : https://gitlab.com/claudiodsf/sourcespec.

The macroseismic intensity database of BCSF-ReNaSS is available at http://www.franceseisme.fr//donnees/BD-MFC.

Macroseismic reports for French earthquake can be downloaded at http://www.franceseisme.fr/donnees/publications.php. 
The database of historical macroseismic intensity SISFRANCE can be found at https://sisfrance.irsn.fr, and data can also be found at AHEAD European Historical macroseimic database (https://www.emidius.eu/AHEAD/).

Shakemaps based on instrumental and microseismic data are available at http://www.franceseisme.fr.

The Website of RESIF is http://www.resif.fr.

Facebook and Twitter social networks (@franceseisme) are

https://www.facebook.com/franceseisme and https://twitter.com/FranceSeisme.

Two European projects are cited : SISPYR: http://www.sispyr.eu and TURNkey: https://earthquake-turnkey.eu/

\section{Acknowledgements}

The authors would like to thank Thomas Lecocq and an anonymous reviewer for their comments which helped to improve the manuscript.

\section{References}

(1) Raspberry Shake Community; (2) OSOP, S.A.; (3) Gempa GmbH. (2016). Raspberry Shake. (1) OSOP, S.A.; (2) gempa GmbH. https://doi.org/10.7914/SN/AM 
Akkar, S., Bommer, J. J. 2010. Empirical equations for the prediction of PGA, PGV and spectral accelerations in Europe, the Mediterranean region and the Middle East. Seismological Research Letters, 81(2), 195-206.

Allen T.I., Wald, D. J., 2009. On the Use of High-Resolution Topographic Data as a Proxy for Seismic Site Conditions (VS30), Bulletin of the Seismological Society of America, 99(2A): 935. http://dx.doi.org/10.1785/0120080255

Atkinson GM, Kaka SI (2007) Relationships between felt intensity and instrumental ground motion in the Central United States and California. Bull Seismol Soc Am 97(2): 497510. https://doi.org/10.1785/0120060154

Atkinson, G. M., Wald , D. J., 2007. "Did You Feel It?" intensity data: A surprisingly good measure of earthquake ground motion. Seismological Research Letters, 78, 362-368.

Auclair, S., Monfort, D., Colas, B., Bertil, D., Rey, J., Winter, T., Langer, T., 2015a. From preparation to operational management of seismic crisis: supporting tools for civil-protection services. GEORISKS IN THE MEDITERRANEAN AND THEIR MITIGATION, 280.

Auclair, S., Monfort, D., Colas, B., Langer, T., Perrier P., 2015b. Evaluation Rapide Des Bilans Matériels et Humains: Une Aide Essentielle à La Gestion Opérationnelle Des Crises Sismiques. In 9ème Colloque National AFPS. Paris.

Bakun, W.H., Scotti, O., 2006. Regional intensity attenuation models for France and the estimation of magnitude and location of historical earthquakes. Geophys J Int 164(3):596-610. 
https://doi.org/10.1111/j.1365-246X.2005.02808.x

Baumont, D., Manchuel, K., Traversa, P., Durouchoux, C., Nayman, E., Ameri, G., 2018. Intensity attenuation models calibrated in Mw for metropolitan France. Bull Earthquake Eng 16: 2285. https://doi.org/10.1007/s10518-018-0344-6

Beauducel F., Bazin, S., Bengoubou-Valérius, M., Bouin, M.-P., Bosson, A., Anténor-Habazac, C., Clouard, V., de Chabalier, J.-C., 2011. Empirical model for rapid macroseismic intensities prediction in Guadeloupe and Martinique, Comptes Rendus Geoscience, 343(11_12):717_728, 2011. doi: 10.1016/j.crte.2011.09.004.

Belinić, T., Markušić, S., 2017. Empirical criteria for the accuracy of earthquake locations on the Croatian territory, Geofizika, 34, DOI: 10.15233/gfz.2017.34.5.

Bertil D., Roviró J., Antonio Jara J., Susagna T., Nus E., Goula X., Colas B., Dumont G., Cabañas L., Anton R. et al., 2012 ShakeMap implementation for Pyrenees in France-Spain border: regional adaptation and earthquake rapid response process. Proceedings of 15 th World Conference on Earthquake engineering: 15th WCEE proceedings - 15th World Conference on Earthquake Engineering : 15th WCEE, Portugal

Bondár, I., McLaughlin, K.L., 2009. A new ground truth data set for seismic studies, Geophysical Research Letter, 80, 465-472.

Bossu, R., Scotti, O., Cotton, F., Cushing, M., \& Levret, A., 2000. Determination of geomechanical site effects in France from macroseismic intensities and reliability of 
macroseismic magnitude of historical events. Tectonophysics, 324(1-2), 81-110.

Bratt S.R., Nagy, W., 1991. The LocSAT Program, Science Applications International Corporation (SAIC), San Diego.

Caprio M., Tarigan, B., Worden,C.B., Wiemer, S., Wald, D.J., 2015. Ground Motion to Intensity Conversion Equations (GMICEs): A Global Relationship and Evaluation of Regional Dependency. Bulletin of the Seismological Society of America, Vol. 105, No. 3, doi: $10.1785 / 0120140286$.

Cara, M., Schlupp, A., Sira, C., 2007. Observations sismologiques : sismicité de la France en 2003, 2004, 2005, Bureau central sismologique français, ULP/EOST - CNRS/INSU, Strasbourg, $199 \mathrm{p}$.

( http://www.franceseisme.fr/donnees/publi/2003-2005/OBS_SISMO_2003-05_W.pdf)

Cara, M., Bruestle, W., Gisler, M., Kästli, P., Sira, C., Weihlermüller, C., Lambert, J., 2005. Transfrontier macroseismic observations of the Ml = 5.4 earthquake of February 22, 2003 at Rambervillers, France, Journal of Seismology 9(3):317-328, DOI: 10.1007/s10950-005-68531

Cara, M., Cansi, Y., Schlupp, A., Arroucau, P., Béthoux, N., Beucler, E., Bruno, S., Calvet, M., Chevrot, S., Deboissy, A., Delouis, B., Denieul, M., Deschamps, A., Doubre, C., Fréchet, J., Godey, S., Golle, O., Grunberg, M., Guilbert, J., Haugmard, M., Jenatton, L., Lambotte, S., Leobal, D., Maron, C., Mendel, V., Merrer, S., Macquet, M., Mignan, A., Mocquet, A., Nicolas, M., Perrot, J., Potin, B., Sanchez, O., Santoire, J.-P., Sèbe, O., Sylvander, M., Thouvenot, F., 
Van der Woerd, J., Van der Woerd, K., 2015. SI-Hex: a new catalogue of instrumental seismicity for metropolitan France. Bull. Soc. géol. France, 186 (1), pp. 3-19.

Chevrot, S., et al., 2014. High-resolution imaging of the Pyrenees and Massif Central from the data of the PYROPE and IBERARRAY portable array deployments, J. Geophys. Res. Solid Earth, 119, 6399-6420, doi:10.1002/2014JB010953.

Courboulex, F., Dujardin, A., Vallée, M., Delouis, B., Sira C., Deschamps, A., Honoré, L., Thouvenot, F., 2013. High-Frequency Directivity Effect for a Mw 4.1 Earthquake, Widely Felt by the Population in Southeastern France. BSSA, 103, 6, doi: 10.1785/0120130073.

Davis, S. D. and C. Frohlich (1993). Did (or will) fluid injection cause earthquakes? - criteria for a rational assessment, Seismological Research Letters, 64, No. 3-4

Denieul, M., Sèbe, O., Cara, M., Cansi, Y., 2015. Mw Estimation from Crustal Coda Waves Recorded on Analog Seismograms, BSSA, 105(2A), doi:10.1785/0120140226.

Duverger C., Mazet-Roux G., Bollinger L., Guilhem Trilla A., Vallage A., Hernandez B., Cansi Y. A decade of seismicity in metropolitan France (2010-2019): the CEA/LDG methodologies and observations. Submitted to BSGF - Earth Sciences Bulletin

Fayjaloun, R, Gehl, P, Auclair, S, Boulahya, F, Guérin-Marthe, S, Roullé, A., 2020. Integrating strong-motion recordings and Twitter data for a rapid shakemap of macroseismic intensity" International Journal of Disaster Risk Reduction, 101927, ISSN 2212-4209. https://doi.org/10.1016/j.ijdrr.2020.101927. 
Federal Institute for Geosciences and Natural Resources. (1976). German Regional Seismic Network (GRSN). Bundesanstalt für Geowissenschaften und Rohstoffe.

https://doi.org/10.25928/mbx6-hr74

French Landslide Observatory - Seismological Datacenter / RESIF. (2006). Observatoire Multi-disciplinaire des Instabilités de Versants (OMIV) [Data set]. RESIF - Réseau Sismologique et géodésique Français. https://doi.org/10.15778/RESIF.MT

Gailler, A., Hébert, H., Loevenbruck, A., and Hernandez, B.: Simulation systems for tsunami wave propagation forecasting within the French tsunami warning center, Nat. Hazards Earth Syst. Sci., 13, 2465-2482, https://doi.org/10.5194/nhess-13-2465-2013, 2013.

Gehl, P., Douglas, J.,D'Ayala, D., 2017. Inferring Earthquake Ground-Motion Fields with Bayesian. Bulletin of the Seismological Society of America, 107(6), 2792-2808.

GEOFON Data Centre. (1993). GEOFON Seismic Network. Deutsches GeoForschungsZentrum GFZ. https://doi.org/10.14470/TR560404

Grünthal, G. (ed.): European Macroseismic Scale 1998 (EMS-98). Cahiers du Centre Européen de Géodynamique et de Séismologie 15, Centre Européen de Géodynamique et de Séismologie, Luxembourg, 99 pp., 1998.

Guérin-Marthe, S., Gehl, P., Negulescu C., Auclair, S., Fayjaloun R. 2020. Rapid earthquake response: the state-of-the art and recommendations with a focus on European 
systems. International Journal of Disaster Risk Reduction, 101958, ISSN 22124209, https://doi.org/10.1016/j.ijdrr.2020.101958.

Helmholtz-Centre Potsdam - GFZ German Research Centre for Geosciences and gempa GmbH, 2008. The SeisComP seismological software package. GFZ Data Services. doi: 10.5880/GFZ.2.4.2020.003.

Hetényi G., Molinari, I., Clinton, J., et al., 2018. The AlpArray Seismic Network: a large-scale European experiment to image the Alpine orogeny. Surveys in Geophysics, 39, 1009-1033. doi:10.1007/s10712-018-9472-4.

Institut De Physique Du Globe De Paris (IPGP), \& Ecole Et Observatoire Des Sciences De La Terre De Strasbourg (EOST). (1982). GEOSCOPE, French Global Network of broad band seismic stations. Institut de physique du globe de Paris (IPGP), Université de Paris. https://doi.org/10.18715/GEOSCOPE.G

Instituto Geografico Nacional, Spain. (1999). Spanish Digital Seismic Network [Data set]. International Federation of Digital Seismograph Networks. https://doi.org/10.7914/SN/ES

Lagomarsino, S., Giovinazzi, S. 2006. Macroseismic and mechanical models for the vulnerability and damage assessment of current buildings. Bull Earthq Eng 2006(4):415-443. doi:10.1007/s10518-006-9024-Z

Landesamt Fuer Geologie, Rohstoffe Und Bergbau. (2009). Landeserdbebendienst BadenWuerttemberg [Data set]. International Federation of Digital Seismograph 
Networks. https://doi.org/10.7914/SN/LE

Locati, M., Rovida, A., Albini, P., \& Stucchi, M., 2014. The AHEAD portal: a gateway to European historical earthquake data. Seismological Research Letters, 85(3), 727-734.

Manchuel, K., Traversa, P., Baumont, D., Cara, M., Nayman, E., \& Durouchoux, C. (2018). The French seismic CATalogue (FCAT-17). Bulletin of Earthquake Engineering, 16(6), 22272251.

Marin S., Avouac J.-P., Nicolas M. and Schlupp A., 2004. A Probabilistic Approach to Seismic Hazard in Metropolitan France, Bulletin of the Seismological Society of America, Vol 94, $\mathrm{N}^{\circ} 6$, pp. 2137-2163, DOI: 10.1785/0120030232.

Martin, C., Combes, P., Secanell, R., Lignon, G., Carbon, D., Fioravanti, A., Grellet, B., 2002 Révision du zonage sismique de la France: étude probabiliste, under the supervision of the Groupe d'Etude et de Proposition pour la Prévention du risque sismique en France and the Association Française du Génie Parasismique (in French), Geoter Report, GTR/MATE/0701150.

Mazabraud Y., Bethoux N., Guilbert J., Bellier 0. (2005) Evidence for short-scale stress field variations within intraplate central-western France, Geophys. J. Int., 160 (1), 161-178

Nicolas M, Béthoux N, Madeddu B. 1998. Instrumental seismicity of the Western Alps: a revised catalogue. Pure and Applied Geophysics, 152, 707-731. 
Pauchet H., Rigo A., Rivera L., Souriau A., (1999) A detailed analysis of the February 1996 aftershock sequence in the eastern Pyrenees, France, Geophys. J. Int., 137, 107-127.

Provost, L., Scotti, O., 2020. QUake-MD: Open-Source Code to Quantify Uncertainties in Magnitude-Depth Estimates of Earthquakes from Macroseismic Intensities, Seismological Research Letters, 91, 2520-2530.

Renouard, A., Grunberg, M., Doubre, C. Maggi, A., 2019. Automatic detection and machine learning-based discrimination of earthquakes in northwestern intraplate Europe using SeisComP3 and the AlpArray network. Geophysical Research Abstracts Vol. 21, p1-1. 1p.

RESIF. (1995a). RESIF-RLBP French Broad-band network, RESIF-RAP strong motion network and other seismic stations in metropolitan France [Data set]. RESIF - Réseau Sismologique et géodésique Français. https://doi.org/10.15778/RESIF.FR

RESIF. (1995b). RESIF-RAP French Accelerometric Network [Data set]. RESIF - Réseau Sismologique et géodésique Français. https://doi.org/10.15778/RESIF.RA

RESIF. (2018). CEA/DASE broad-band permanent network in metropolitan France [Data set]. RESIF - Réseau Sismologique et géodésique Français. https://doi.org/10.15778/RESIF.RD

Rey, J., Tinard, P., 2015. Estimation financière du risque sismique à l'échelle départementale: à l'interface entre sismologie et réassurance, travaux communs CCR-BRGM (2014-2019). 
Riedel, I., Guéguen, P., Dalla Mura, M., Pathier, E., Leduc, T., Chanussot, J., 2015. Seismic vulnerability assessment of urban environments in moderate-to-low seismic hazard regions using association rule learning and support vector machine methods. Natural hazards, 76(2), $1111-1141$

Rojo, M. B., Beck, E., \& Lutoff, C. (2017). The street as an area of human exposure in an earthquake aftermath: the case of Lorca, Spain, 2011.

Rothé J.P. and Peterschmitt E. (1950). - Étude séismique des explosions d'Haslach. - Ann. Inst. Phys. Globe Strasbourg, 5, 3e part. Géophysique, 13-28.

Royal Observatory Of Belgium. (1985). Belgian Seismic Network [Data set]. International Federation of Digital Seismograph Networks. https://doi.org/10.7914/SN/BE

Satriano C., SourceSpec - Earthquake source parameters from S-wave displacement spectra, https://doi.org/10.5281/zenodo.3765327

Sbarra, P., De Rubeis, V., Di Luzio, E., Mancini, M., Moscatelli, M., Stigliano, F., ... \& Vallone, R. (2012). Macroseismic effects highlight site response in Rome and its geological signature. Natural hazards, 62(2), 425-443.

Schindelé, F., Gailler, A., Hébert, H. et al. Implementation and Challenges of the Tsunami Warning System in the Western Mediterranean. Pure Appl. Geophys. 172, 821-833 (2015). https://doi.org/10.1007/s00024-014-0950-4 
Schlupp, A., Chavot, Ph., Grunberg, M. , Bès De Berc, M., Jund, H., Ajak, F., Vergne, J., Masson, F., Schmittbuhl, J., 2019a. SeismoCitizen : A project combining seismology and human science approaches based on a deployment of a dense low cost seismic network hosted by citizens. European Geosciences Union, General Assembly, 7-12 avril 2019, Vienna, Austria.

Schlupp A., Grunberg, M., Bertil, D., Schaming, M., Ulrich, A., 2019b. Les « ShakeMap » pour les territoires français : un produit pour la gestion de crise et un outil R\&D pour l'estimation de l'aléa. 10ème Colloque national AFPS, 24-27 septembre 2019, Strasbourg.

Scotti, O., Baumont, D., Quenet, G., Levret, A., 2004. The French macroseismic database SISFRANCE: objectives, results and perspectives. Annals of geophysics, 47, 30.

Sedan O., M. Terrier, C. Negulescu, A. Roullé, T. Winter, D. Bertil (2013) Armagedom - A Tool for Seismic Risk Assessment Illustrated with Applications, Journal of Earthquake Engineering, 17:2, 253-281.

Sira, C., Schlupp, A., \& Schaming, M. (2010). Sismocom: Application mobile pour témoigner et être informé sur les séismes. Mappemonde, 99(3)., Revue de l'institut SHS du CNRS , https://mappemonde-archive.mgm.fr/num27/fig10/fig10304.html

Sira, C., 2015. Macroseismic Intervention Group: The Necessary Field Observation. In: Ansal A. (eds) Perspectives on European Earthquake Engineering and Seismology. Geotechnical, Geological and Earthquake Engineering, p 395-408, vol 39. Springer, Cham. DOI https://doi.org/10.1007/978-3-319-16964-4_16 
Sira, C., Schaming, M., Delouis, B., Satriano, C., 2019. Séisme de Tancoigné du 21 juin 2019, Rapport sismologique, BCSF-RENASS2019-R2, 47 pages, 3 tableaux, 13 figures, 8 annexes, (http://www.franceseisme.fr/donnees/intensites/2019/190621_0650/Note\%20BCSFRENASS\%20Seisme190621-BD.pdf)

Souriau, A., 2006. Quantifying felt events: a joint analysis of intensities, accelerations and dominant frequencies, Tectonophysics , 10:23. https://doi.org/10.1007/s10950-006-2843-1

Strollo et al. (2020) EIDA : the European Integrating Data Archive and service infrastructure within ORFEUS, submitted to this SRL issue.

Swiss Seismological Service (SED) At ETH Zurich. (1983). National Seismic Networks of Switzerland. ETH Zürich. https://doi.org/10.12686/sed/networks/ch

Tellez-Arenas, A., Hohmann, A., Quentin, A., Negulescu, C., Smaï, F., 2019. A web platform for storing, sharing and executing scientific workflows for Natural Risk Assessment: part 2 description of an interoperable architecture based on open-source components. EGU General Assembly 2019, Apr 2019, Vienne, Austria. pp.2019 - 7800, 2019. 〈hal-02075035〉

Thouvenot F., Fréchet J., Jenatton L., Gamond J.-F. (2003) The Belledonne Border Fault: identification of an active seismic strike-slip fault in the western Alps, Geophy. J. Int., 155(1), 174-192, https://doi-org.insu.bib.cnrs.fr/10.1046/j.1365-246X.2003.02033.x

Traversa, P., Baumont, D., Manchuel, K., Nayman, E. 2017. Exploration tree approach to estimate historical earthquakes Mw and depth, test cases from the French past seismicity. Bull 
Earthq Eng. https://doi:10.1007/s10518-017-0178-7

University Of Genova. (1967). Regional Seismic Network of North Western Italy.

International Federation of Digital Seismograph Networks. https://doi.org/10.7914/SN/GU

Veinante-Delhaye A, Santoire J.-P., 1980. Sismicité récente de l'Arc Sud Armoricain et du Nord-Ouest du Massif Central. Mécanismes au foyer et tectonique. Bulletin de la Société Géologique de France, 7(1), XXII, 93-102.

Wald, D.J., Quitoriano, V., Heaton, T.H., Kanamori, H., Scrivner, C.W., Worden, C.B., 1999. Trinet "ShakeMaps": rapid generation of peak ground motion and intensity maps for earthquakes in Southern California. Earthq Spectra 15(3):537-555

Wald, D. J., Allen T.I., 2007. Topographic Slope as a Proxy for Seismic Site Conditions and Amplification. Bulletin of the Seismological Society of America, 97(5): 1379 http://dx.doi.org/10.1785/0120060267

Woessner, J., Laurentiu, D., Giardini, D., Crowley, H., Cotton, F., Grünthal, G., ... \& Hiemer, S. (2015). The 2013 European seismic hazard model: key components and results. Bulletin of Earthquake Engineering, 13(12), 3553-3596.

Worden, C.B., D.J. Wald, T.I. Allen, K.W. Lin, D. Garcia, and G. Cua, 2010. A revised groundmotion and intensity interpolation scheme for ShakeMap, Bull. Seism. Soc. Am. 100(6), 30833096. 
Worden, C B, Thompson, E.M., Baker, J.W., Bradley, B.A., Luco, N., Wald, D., 2018. Spatial and Spectral Interpolation of Ground-motion Intensity Measure Observations, Bulletin of the Seismological Society of America 108 (2): 866-75.

Worden, C. B., Thompson, E. M., Hearne, M., Wald, D. J., 2020. ShakeMap Manual Online: technical manual, user's guide, and software guide, U. S. Geological Survey. http://usgs.github.io/shakemap/. 


\section{Mail address and email of the authors}

Frédéric Masson

EOST and ITES, Université de Strasbourg/CNRS, 5 rue Descartes, 67084 Strasbourg Cedex, France

frederic.masson@unistra.fr

Samuel Auclair

BRGM, Department of Risks and Prevention, 3 av. Claude-Guillemin - BP 36009, 45060

Orléans Cedex 2 - France

s.auclair@brgm.fr

Didier Bertil

BRGM, Department of Risks and Prevention, 3 av. Claude-Guillemin - BP 36009, 45060

Orléans Cedex 2 - France

d.bertil@,brgm.fr

Marc Grunberg

EOST, Université de Strasbourg/CNRS, 5 rue Descartes, 67084 Strasbourg Cedex, France marc.grunberg@,unistra.fr

Bruno Hernandez

CEA, DAM, DIF, 91297 Arpajon, France

Bruno.HERNANDEZ@cea.fr 
Sophie Lambotte

EOST and ITES, Université de Strasbourg/CNRS, 5 rue Descartes, 67084 Strasbourg Cedex, France

sophie.lambotte@unistra.fr

Gilles Mazet-Roux

CEA, DAM, DIF, 91297 Arpajon, France

Gilles.MAZET-ROUX@,cea.fr

Ludmila Provost

Bureau d'évaluation des risques sismiques pour la sûreté des installations, Institut de

Radioprotection et Sûreté Nucléaire, Fontenay-aux-Roses, France

ludmila.provost@irsn.fr

Jean-Marie Saurel

IPGP, Université de Paris/CNRS, 1, rue Jussieu - 75238 Paris cedex 05, France

saurel@ipgp.fr

Antoine Schlupp

EOST and ITES, Université de Strasbourg/CNRS, 5 rue Descartes, 67084 Strasbourg Cedex, France

antoine.schlupp@unistra.fr

Christophe Sira

EOST, Université de Strasbourg/CNRS, 5 rue Descartes, 67084 Strasbourg Cedex, France 
Christophe.sira@unistra.fr 


\section{Figures}

Figure 1: map of seismological stations (using International FDSN station name) used to localize the metropolitan France seismicity : France (RESIF: FR, RD, RA), AM (RaspberryShake), England (GB), Switzerland (CH), Belgium (BE), Italy Genoa (GU), Germany (LE).

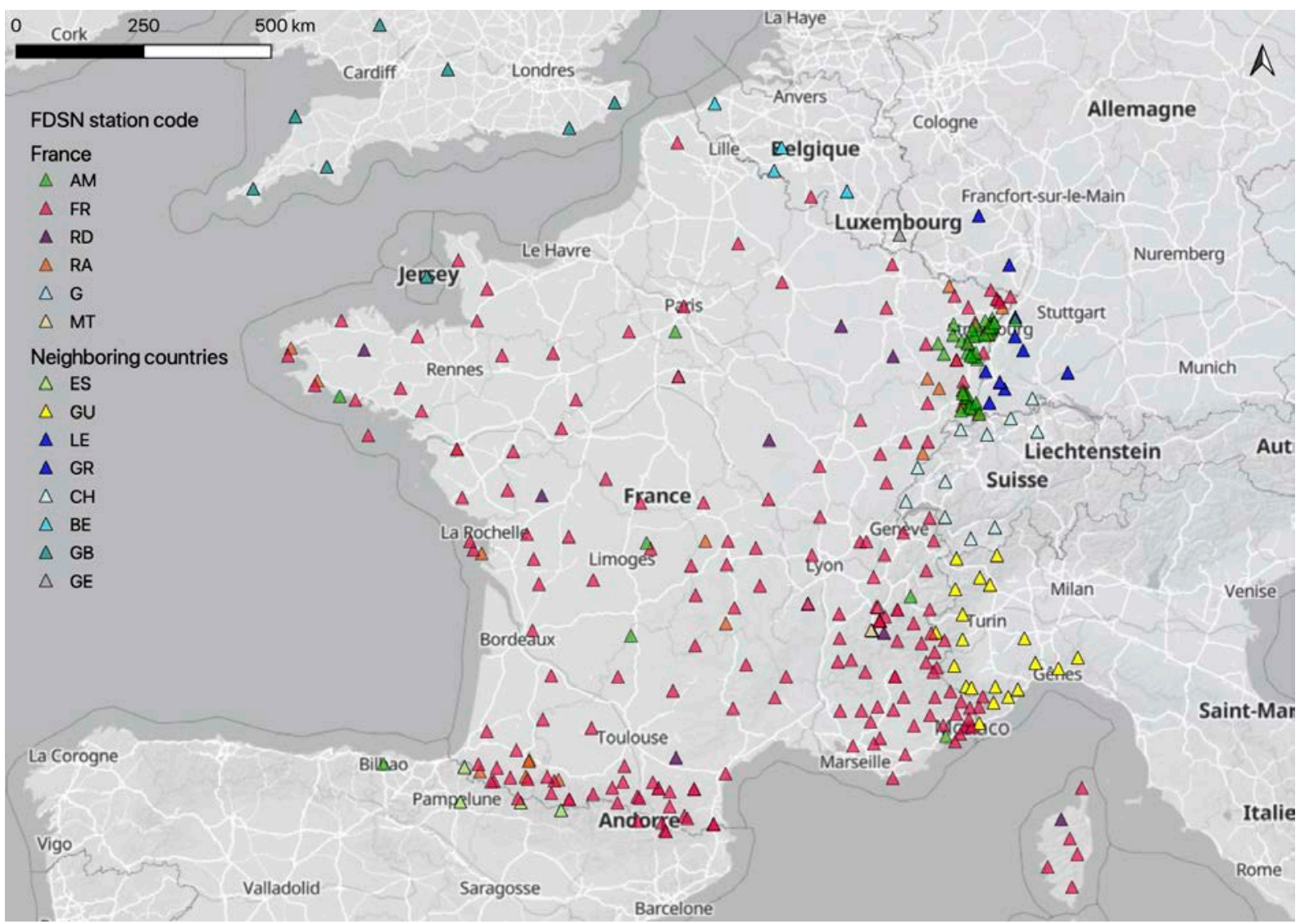


Figure 2: number of events located per year by BCSF-RéNaSS since 1980. From 2012, a discrimination is made between natural earthquake (blue), quarry-related activity (red), landslide (yellow), induced earthquake (grey). The black curve indicates the number of stations used for location.

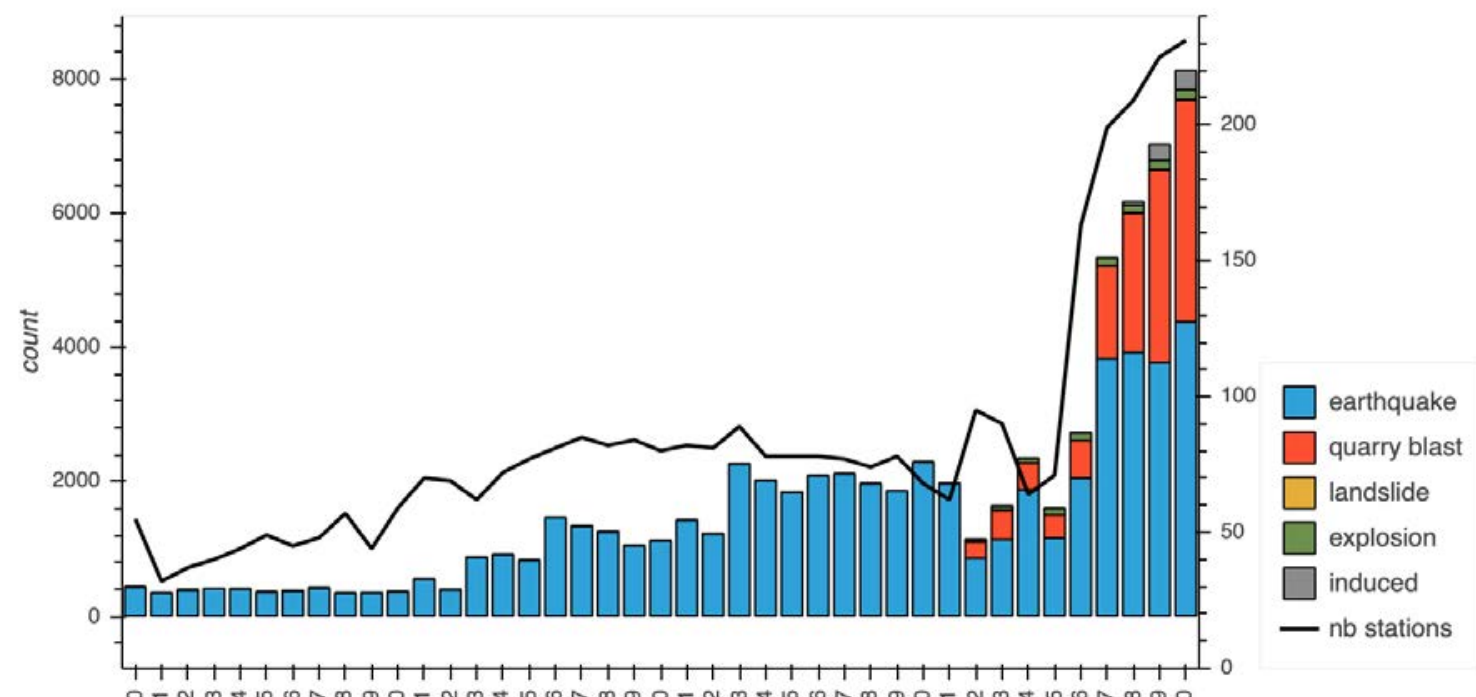

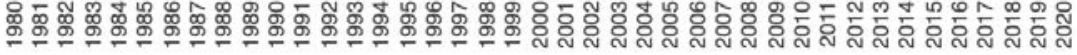

year 
Figure 3: rate of localized earthquakes with a GT5 criterion (95\% confidence) per year by the LDG since 1963.

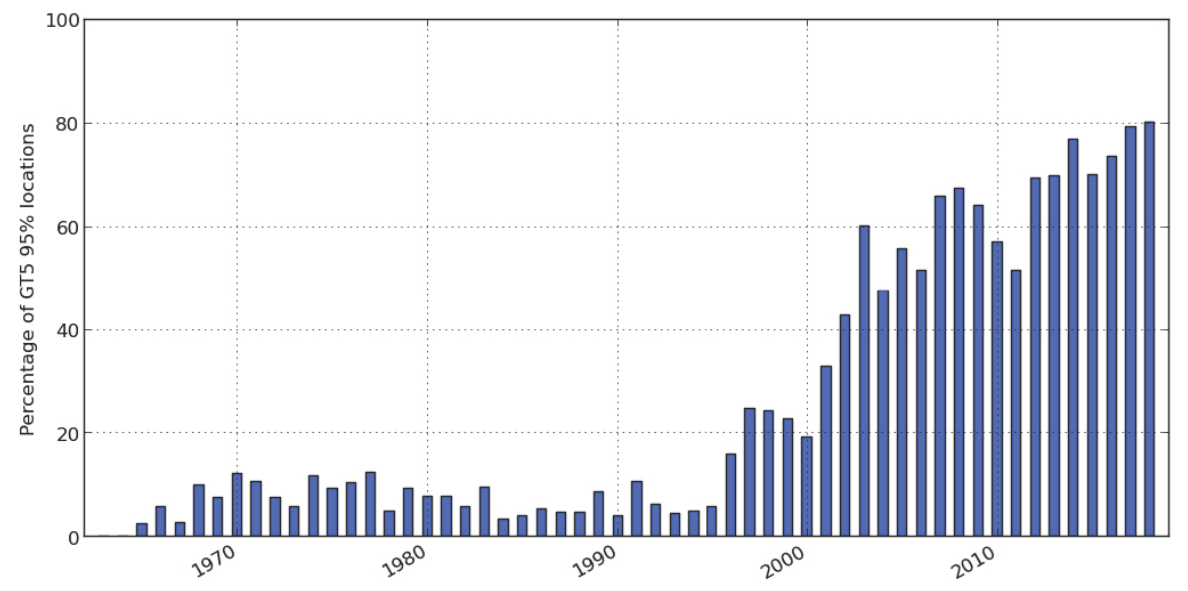


Figure 4: Map of preliminary intensities from the internet testimonies

\section{Preliminary macroseismic intensities and information}

Teil earthquake (11h52 local time on $11 / 11 / 19, M=5.2$, prof. $2 \mathrm{~km}$ ) according to BCSF-RENASS

Date (in universal time): 11/11/2019

Time (in universal time): 10:52 a.m.

\section{Magnitude: 5.2}

\section{Coordinates : \\ Latitude : $44.53^{\circ} \mathrm{N}$ \\ Longitude : $4.64^{\circ} \mathrm{E}$}

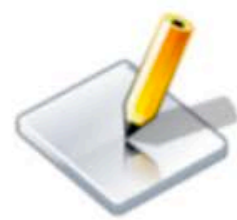

Testify about this earthquake

Why?

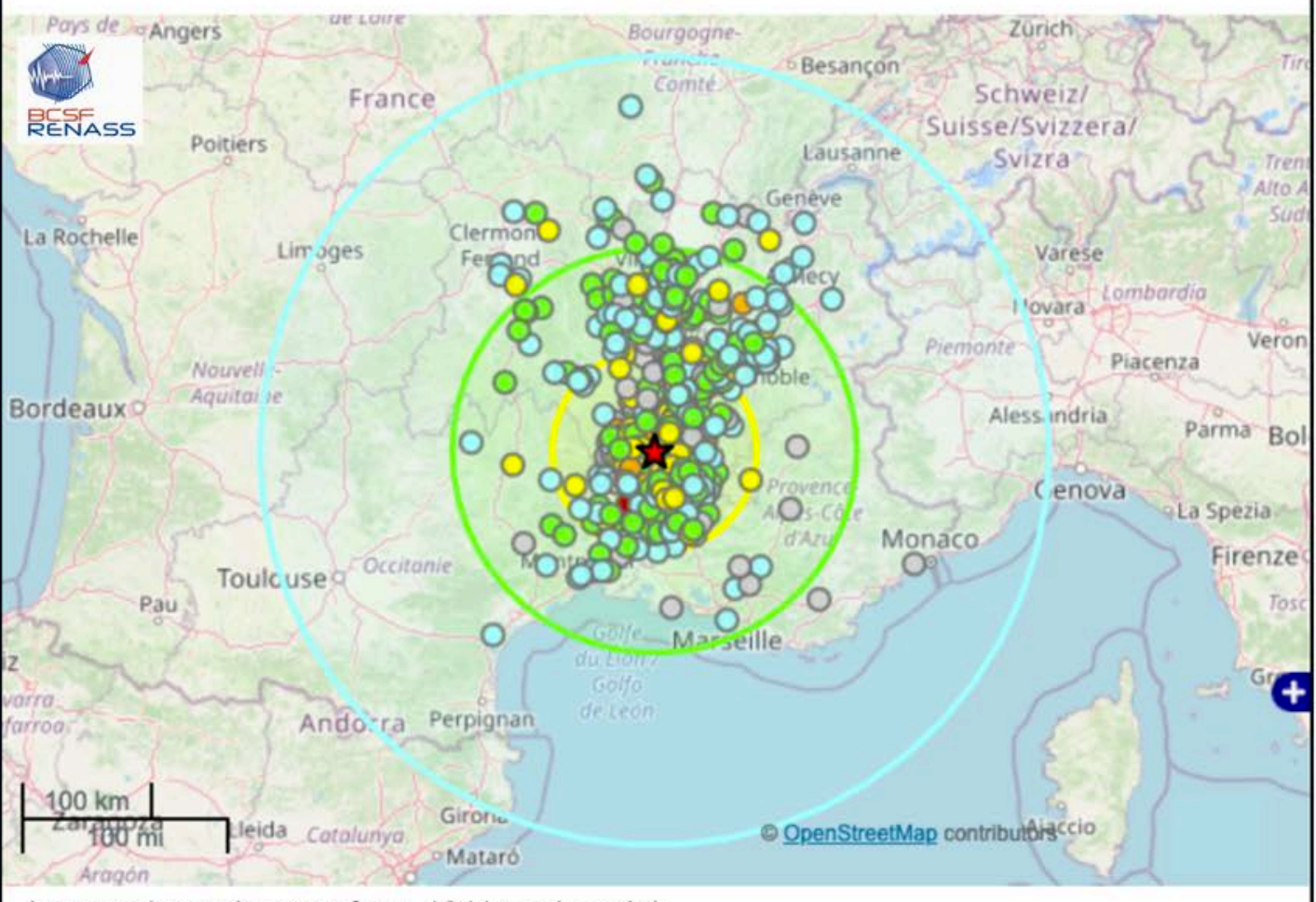

Internet intensity map from 1811 testimonials

\begin{tabular}{|c|c|c|c|c|c|c|c|c|c|c|}
\hline Intensity EMS98 & I & II & III & IV & V & VI & VII & VIII & IX & $x+$ \\
\hline $\begin{array}{l}\text { Potential damage } \\
\text { weak } \\
\text { buildings }\end{array}$ & no & no & no & no & very low & moderate & $\begin{array}{l}\text { few } \\
\text { partial } \\
\text { collaps }\end{array}$ & $\begin{array}{l}\text { many } \\
\text { partial } \\
\text { collaps }\end{array}$ & $\begin{array}{l}\text { many } \\
\text { collaps }\end{array}$ & $\begin{array}{l}\text { widespread } \\
\text { collaps }\end{array}$ \\
\hline $\begin{array}{l}\text { Potential damage } \\
\text { low-vulnerability } \\
\text { buildings }\end{array}$ & no & no & no & no & no & no & very low & moderate & $\begin{array}{l}\text { partial } \\
\text { collaps }\end{array}$ & $\begin{array}{l}\text { many } \\
\text { collaps }\end{array}$ \\
\hline Human perception & not felt & very weak & weak & light & moderate & strong & very strong & severe & violent & extreme \\
\hline
\end{tabular}


Figure 5: Map of Internet users' reactions to the earthquake (Teil earthquake 11/11/2019, $\mathrm{M}=5.2)$

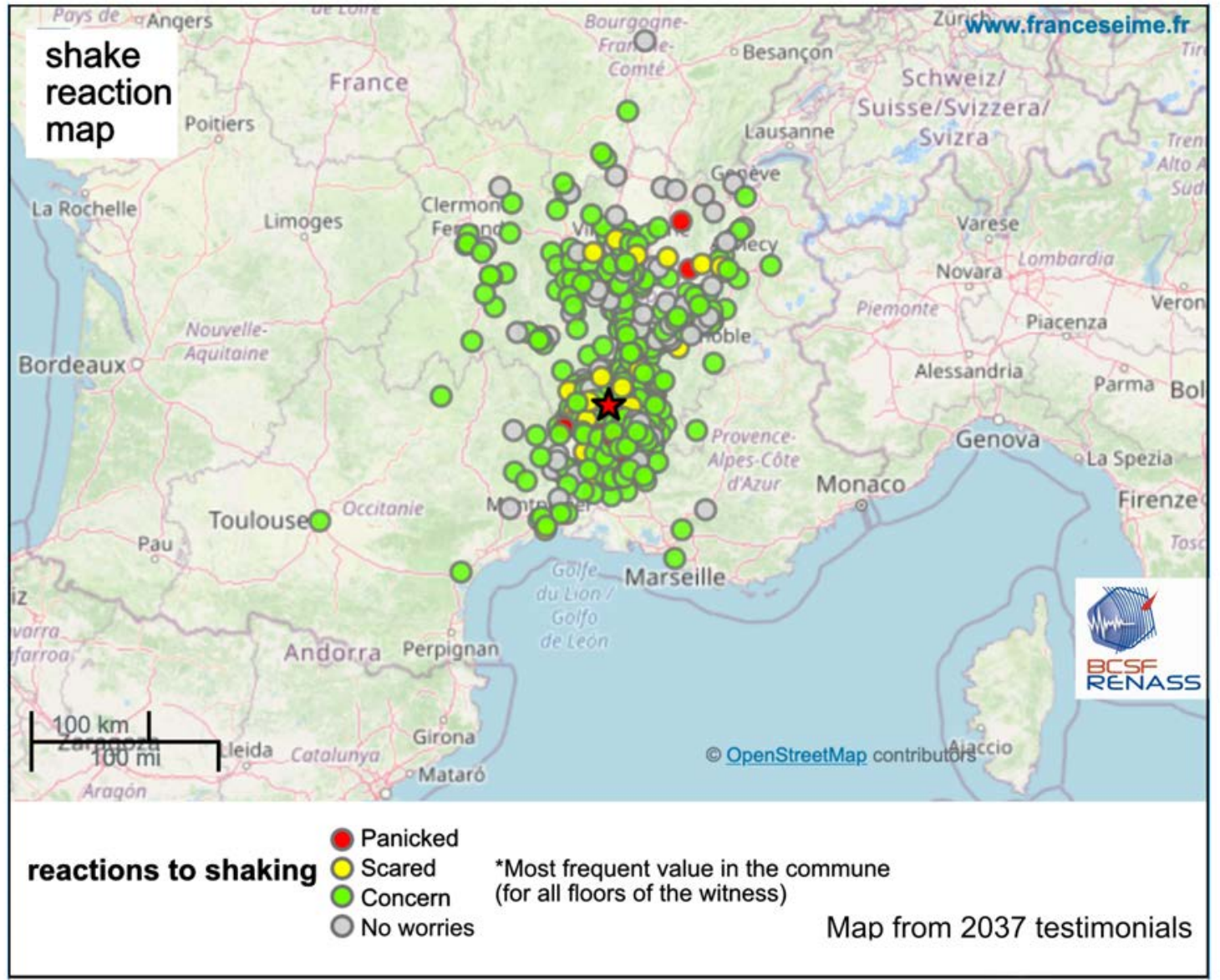


Figure 6: Macroseismic map of the epicentral zone of the Teil earthquake (November 2019, $\mathrm{M}=5.2$ ) based on final EMS98 communal intensities.

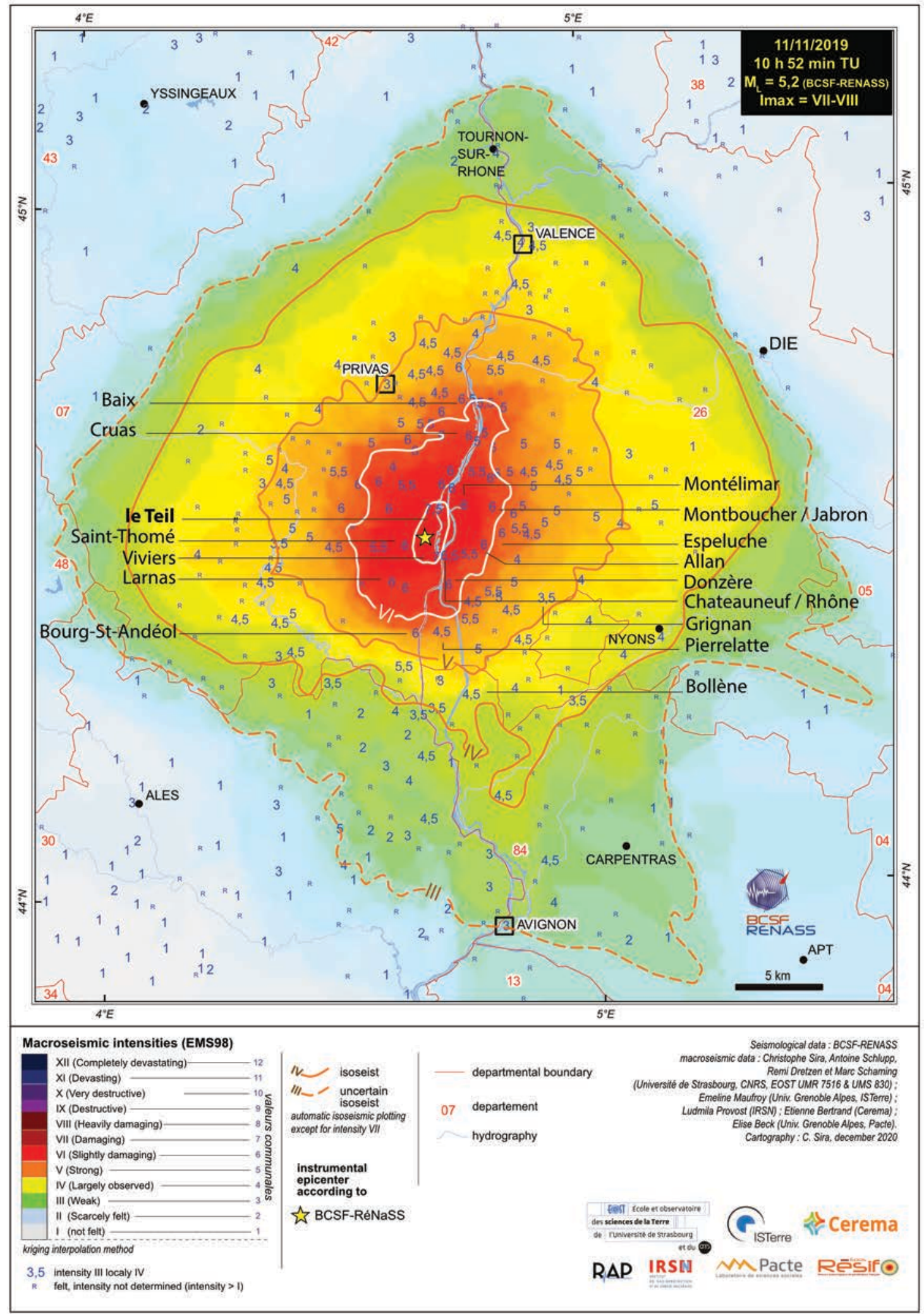


Figure 7: shakemap for the 2019-06-21 earthquake in Intensity scale.

ShakeMap based on instrumental and macroseismic data Earthquake of 2019/06/21 at 08h51 (local time) 21/06/2019 06:50:57 GMT M $5.147 .15^{\circ} \mathrm{N} 0.34^{\circ} \mathrm{W}$ [after CEA-LDG] / Depth: $12 \mathrm{~km}$ (fixed)

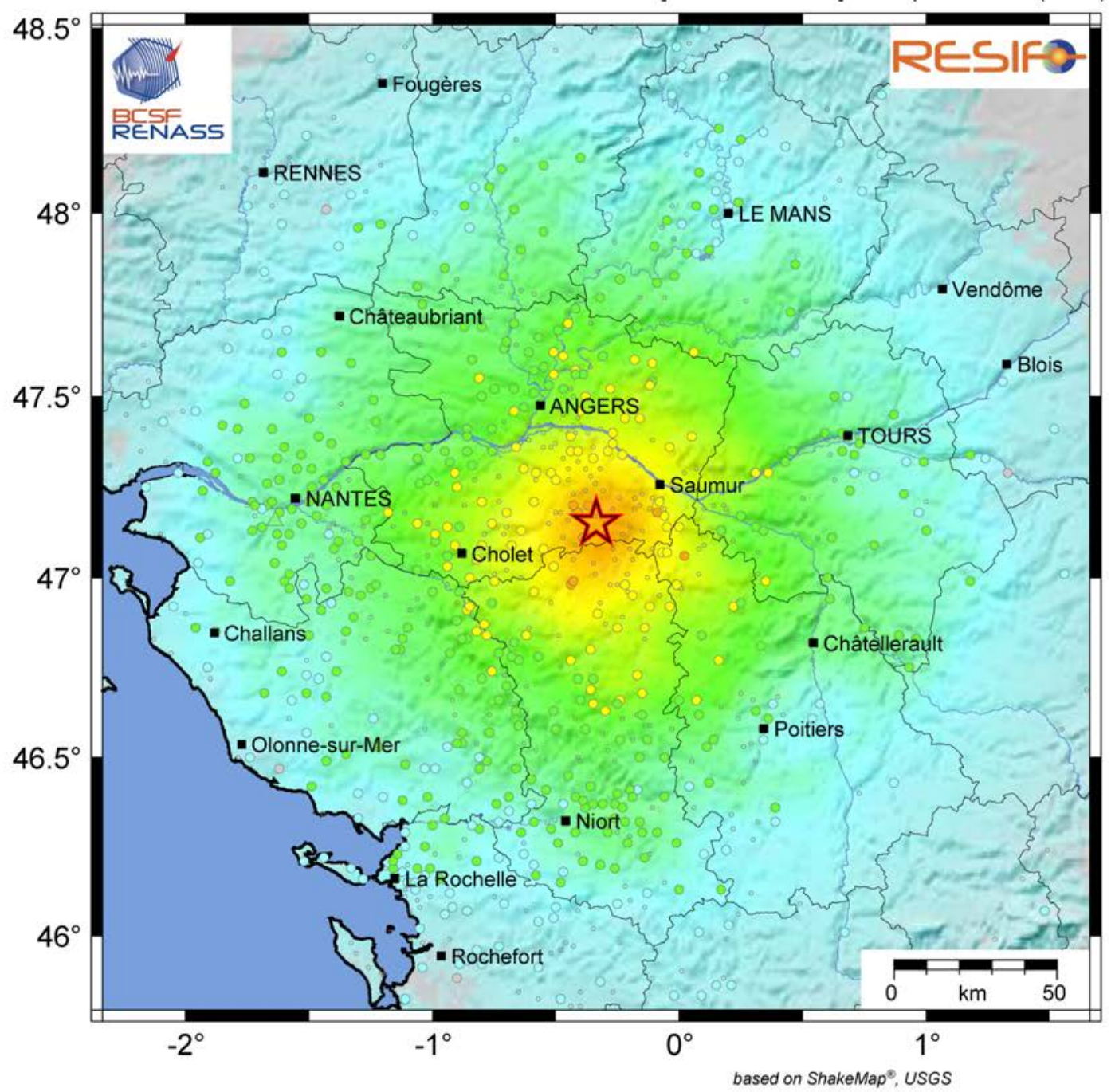

\begin{tabular}{|c|c|c|c|c|c|c|c|c|c|c|}
\hline Intensity EMS98 & I & II & III & IV & V & VI & VII & VIII & IX & $x+$ \\
\hline $\begin{array}{c}\begin{array}{c}\text { Potential damage } \\
\text { weak } \\
\text { buildings }\end{array} \\
\end{array}$ & no & no & no & no & very low & moderate & $\begin{array}{l}\text { few } \\
\text { partial } \\
\text { collaps }\end{array}$ & $\begin{array}{l}\text { many } \\
\text { partial } \\
\text { collaps }\end{array}$ & $\begin{array}{l}\text { many } \\
\text { collaps }\end{array}$ & $\begin{array}{l}\text { widespread } \\
\text { collaps }\end{array}$ \\
\hline $\begin{array}{c}\text { Potential damage } \\
\text { low-vulnerability } \\
\text { buildings }\end{array}$ & no & no & no & no & no & no & very low & moderate & $\begin{array}{l}\text { partial } \\
\text { collaps }\end{array}$ & $\begin{array}{l}\text { many } \\
\text { collaps }\end{array}$ \\
\hline Human perception & not felt & very weak & weak & light & moderate & strong & very strong & severe & violent & extreme \\
\hline
\end{tabular}

\begin{tabular}{|c|c|c|}
\hline $\begin{array}{c}\text { Contributes to } \\
\text { the calculation }\end{array}$ & $\begin{array}{l}\text { Does not } \\
\text { contribte to } \\
\text { the salculation }\end{array}$ & Observation type \\
\hline \hdashline & - & Intensity after macroseismic data (online testimonies) \\
\hline$\triangle$ & $\Delta$ & $\begin{array}{r}\text { Intensity from conversion of PGA / PGV (instrumental data) } \\
\text { Comversion PGA, PGV/intensity based on Caprio et al. (2015) }\end{array}$ \\
\hline
\end{tabular}


Figure 8: shakemaps in PGA, PGV and PSA $(0.3,1.0,3.0 \mathrm{sec})$ for the earthquake of 2019/06/21 at $06: 50: 57 \mathrm{TU}, \mathrm{ML}=5.1$ located at $47.15^{\circ} \mathrm{N} 0.34^{\circ} \mathrm{W}$ [after CEA-LDG]. The depth is fixed at $12 \mathrm{~km}$ (by default in our procedure

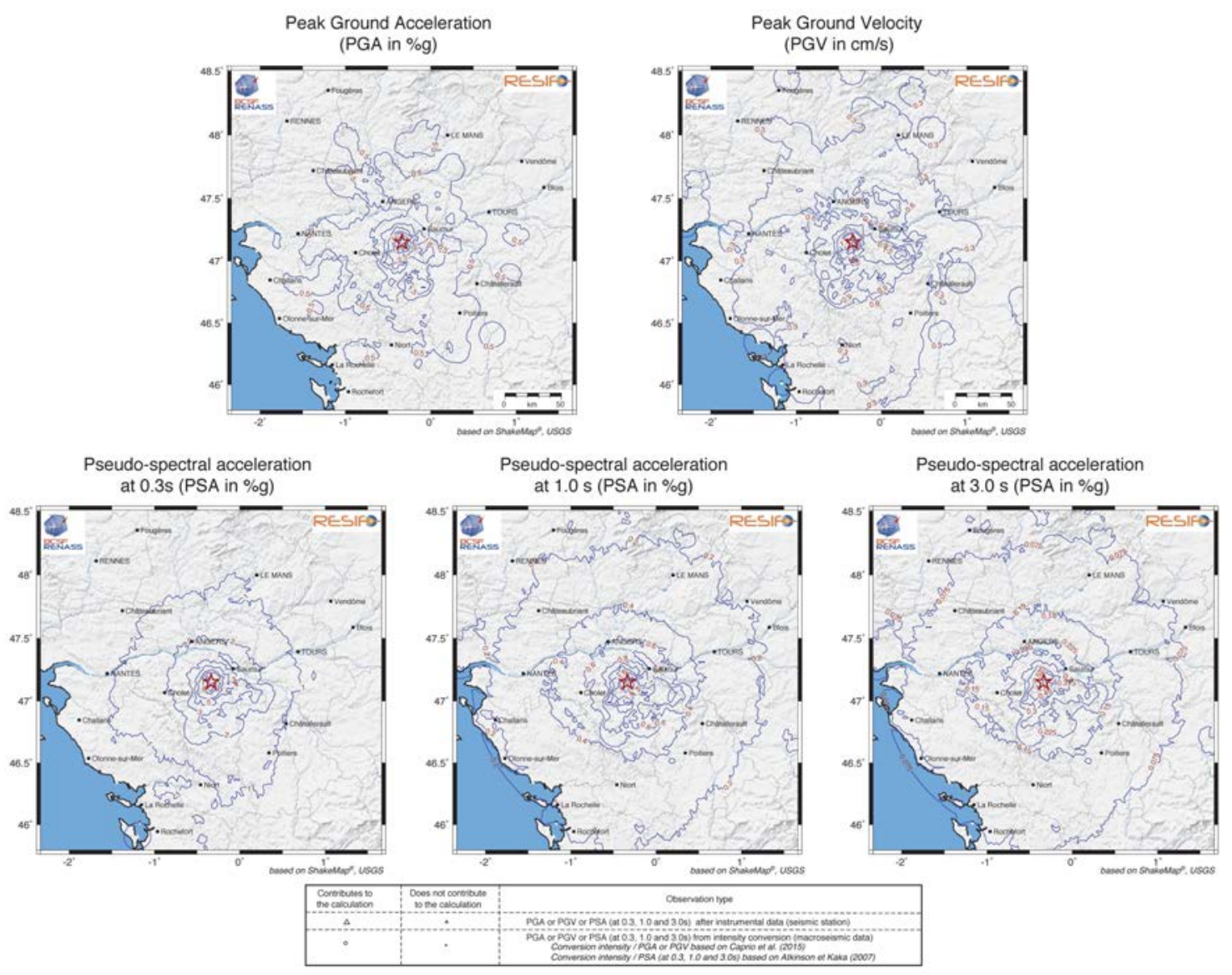


Figure 9: regression curves for the 2019-06-21 earthquake in Intensity scale. Notice the magnitude correction (Bias) of 0.55 necessary to fit attenuation law and data (move from red line to black line). Good fit between Intensity (circle) and few station measurements converted in Intensity (triangle) based on Caprio et al. 2015. Area in blue $=3$ sigma std.

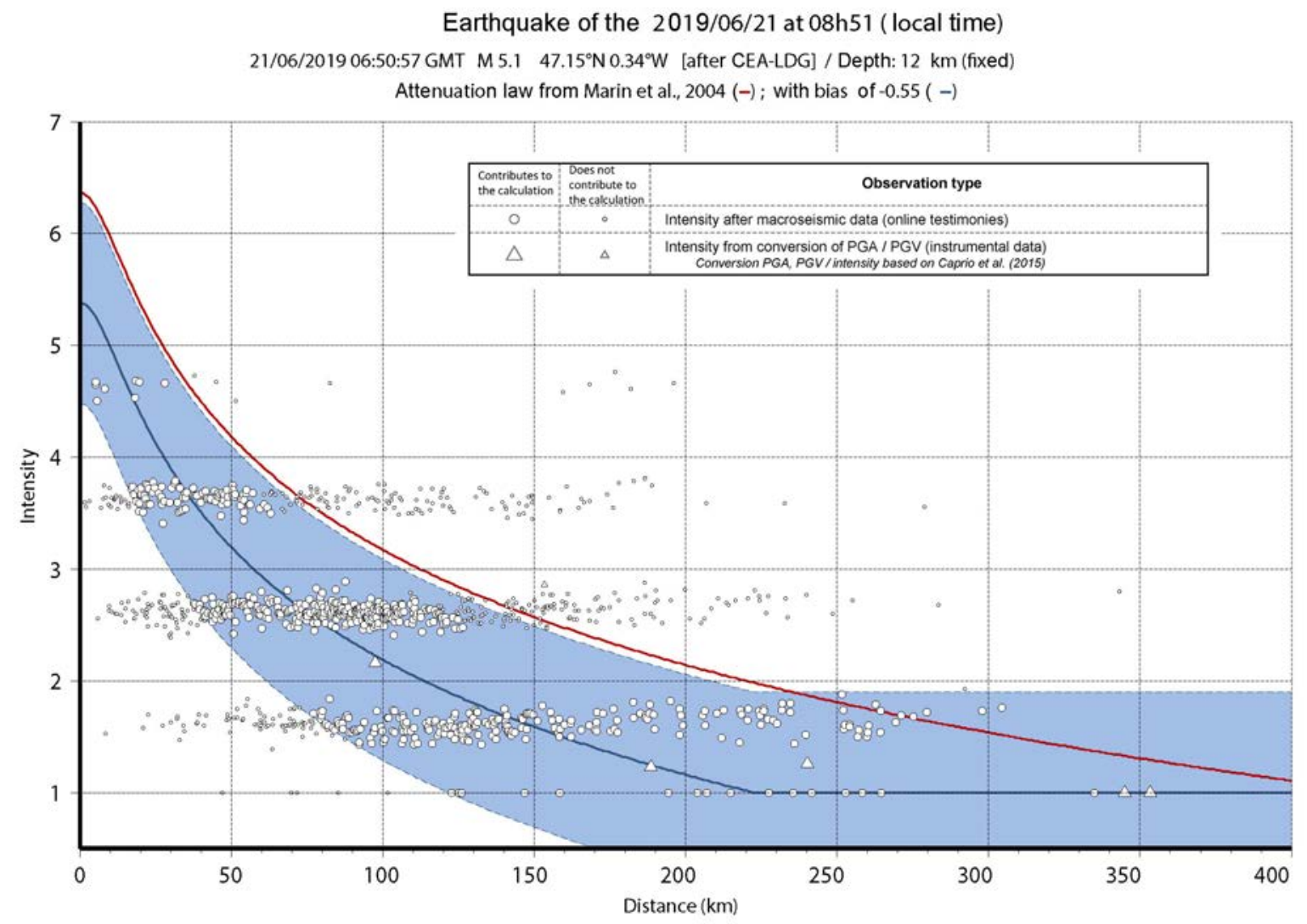


Table 1: a- list of the organisations involved in the Tranversal Seismic Action RESIF. Binvolvement of each organisation in the axes of the action.

\begin{tabular}{|l|l|}
\hline \multicolumn{1}{|c|}{ ACRONYM } & \multicolumn{1}{c|}{ NAME OF ORGANIZATION } \\
\hline BRGM & Bureau de recherches géologiques et minières \\
\hline CEA / LDG & $\begin{array}{l}\text { Commissariat à l'énergie atomique et aux énergies renouvelables / } \\
\text { Laboratoire de détection géophysique }\end{array}$ \\
\hline IRSN & Institut de radioprotection et de sécurité nucléaire \\
\hline IPGP & Institut de physique du globe de Paris \\
\hline OCA & Observatoire de la Côte d'Azur \\
\hline EOST / BCSF-RéNaSS & $\begin{array}{l}\text { Ecole et observatoire des sciences de la Terre / Bureau central } \\
\text { sismologique français - Réseau national de surveillance sismique }\end{array}$ \\
\hline OMP & Observatoire Midi-Pyrénées \\
\hline OSUG & Oservatoire des sciences de l'Univers de Grenoble \\
\hline OSUNA & Oservatoire des sciences de l'Univers de Nantes - Atlantique \\
\hline
\end{tabular}

\begin{tabular}{|c|c|c|c|c|}
\hline ORGANISATION & Axe 1 & Axe 2 & Axe 3 & Axe 4 \\
\hline & 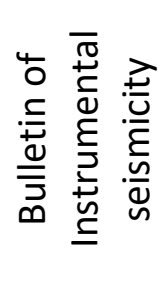 & 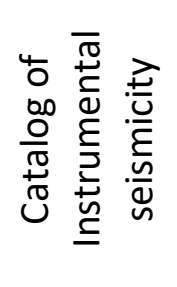 & 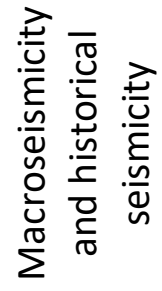 & $\begin{array}{l}\frac{0}{\pi} \\
\frac{\varepsilon}{d} \\
\frac{\sqrt{\pi}}{\tilde{N}} \\
\frac{\pi}{n}\end{array}$ \\
\hline BRGM & & & $x$ & $x$ \\
\hline CEA / LDG & $x$ & $X$ & & \\
\hline IRSN & & $X$ & $x$ & \\
\hline IPGP & $x$ & $x$ & $x$ & \\
\hline OCA & $x$ & & & $x$ \\
\hline EOST / BCSF-RéNaSS & $x$ & $\mathrm{X}$ & $x$ & $\mathrm{X}$ \\
\hline OMP & $x$ & & & \\
\hline OSUG & $x$ & & & \\
\hline OSUNA & $x$ & & & \\
\hline
\end{tabular}

